\title{
LOS PRECURSORES DE LA TOLERANCIA EN LA ESPAÑA DEL SIGLO XVI
}

HÉCTOR ÁLVAREZ GARCÍA 


\section{SUMARIO}

1. APROXIMACIÓN CONCEPTUAL. 2. EL HUMANISMO CRISTIANO. 3. LOS ERASMISTAS ESPAÑOLES. 4. LA IMPRONTA HUMANISTA EN LA COLONIZACIÓN AMERICANA. 5. EL HUMANISMO LAICO. 6. CONCLUSIONES. 


\title{
LOS PRECURSORES DE LA TOLERANCIA EN LA ESPAÑA DEL SIGLO XVI
}

\author{
HÉCTOR ÁLVAREZ GARCÍA* \\ Profesor de Derecho Constitucional \\ Universidad Pablo de Olavide
}

\section{APROXIMACIÓN CONCEPTUAL}

Tomás y Valiente sostiene que el término tolerancia presenta cuatro acepciones nítidamente diferenciadas: la primera está ligada a la indulgencia, que se caracteriza por la inclinación benevolente hacia las faltas de los demás; la segunda está conectada con el pragmatismo: no se reprime un desafuero por debilidad personal, institucional o pura conveniencia; la tercera está unida a la gracia: la magnánima autoridad condesciende con sus ofensores al modo de Augusto — según refiere Séneca en De Clementia - o con la heterodoxia permitiendo que acceda al mercado de las creencias, a la manera de Enrique IV de Francia; y la cuarta está imbricada con la igualdad y la libertad, que constituyen las señas de identidad del pensamiento ilustrado, cuyos orígenes se fraguaron en el reconocimiento de la dignidad del hombre por el humanismo cristiano, y que constituyen el cañamazo axiológico de las primeras declaraciones de los derechos humanos alumbradas por el constitucionalismo liberal.

Rus Rufino destaca dos vertientes de esta virtud cívica, a saber, una pasiva, ligada al indiferentismo vive $y$ deja vivir: se tolera la enojosa diversidad que no se puede reducir a la unidad (el mal menor). El referente histórico-político en la Europa de las creencias fue la Paz de Augsburgo (1555), en la que se instituyó el principio cuius regio, eius religio, cuyo radio de acción se proyectó sobre la Confederación de Varsovia de 1573 y el Edicto de Nantes de 1598. Esta precaria libertad de conciencia - «bien poco es no hacer daño a quien se debe favorecer» (Séneca)- dominó el Viejo Continente hasta que las revoluciones liberales subrayaron la dimensión activa de la tolerancia, vinculada al reconocimiento jurídico de la pluralidad, la libertad y la igualdad: valores

* Profesor Ayudante Doctor de Derecho Constitucional. Universidad Pablo de Olavide, Despacho: 14.03.24, Crta. de Utrera, Km.1, 41013, Sevilla. Email: halvgar@upo.es

(C) UNED. Revista de Derecho Político 
inescindibles de la dignidad humana y signos identitarios de la sociedad humanista e ilustrada, que arrumba el pensamiento único y ejerce su égida sobre la heterodoxia y la disidencia política ${ }^{1}$.

El despunte doctrinal, sin embargo, lo encontramos en la obra Respecto a los herejes y a quienes los queman (1525) del anabaptista Hübmaier: «Los inquisidores son los mayores herejes, ya que, contra la doctrina y el ejemplo de Cristo, les condenan al fuego y arrancan el trigo con la cizaña antes del tiempo de la cosecha. Porque Cristo no vino a matar, destruir y quemar sino para que los que viven pudieran vivir más plenamente» ${ }^{2}$. Y la floración práctica la hallamos en la ciudad polaca de Rakow, reducto efímero de la libertad religiosa y polo de atracción académica para librepensadores, en la que los discípulos socinianos publicaron en 1605 el Catecismo Racoviano, en el que reflejaron la doctrina liberal de su maestro Socino:

«Con la publicación de este Catecismo no intentamos imponer nada a nadie. Al exponer nuestra opinión no oprimimos a nadie. Que todos sean libres de expresar sus ideas en los asuntos religiosos, con tal de que también se nos permita a nosotros expresar nuestra opinión sobre las cosas divinas sin sufrir daño o recibir insultos (...) En lo que a nosotros respecta, todos somos hermanos y no se nos ha dado ningún poder ni autoridad sobre la conciencia de los demás. Aunque entre los hermanos hay unos más sabios que otros, todos son iguales en la libertad y el derecho de filiación» ${ }^{3}$.

La etimología, no obstante, es concluyente: «(...) el sustantivo latino tolerantia significa «paciencia», y toleratio alude a la «capacidad para el sufrimiento». Por su parte, el verbo tolerare se traduce por «llevar, sostener, soportar, aguantar, resistir», así como «sustentar, mantener, combatir o aliviar el hambre con algo»; el adverbio toleranter equivale a «pacientemente, con resignación», y el participio tolerans se refiere a «quien sobrelleva, soporta o resiste»». Así pues, parece evidente que el origen del vocablo tolerar está unido a las dos primeras acepciones del término que señala el Diccionario de la Lengua Española de la Real Academia: «1 ${ }^{a}$. Llevar con paciencia. $2^{a}$. Permitir algo que no se tiene por lícito sin aprobarlo expresamente». No obstante, debemos consignar que nuestro Diccionario introduce una inflexión en la voz «tolerancia», fruto de la influencia de la ideología constitucional que ha forzado su costura semántica: «el respeto a las ideas, creencias o prácticas de los demás cuando son diferentes o contrarias a las propias». En efecto, como agudamente señala Barrio Maestre: «Tolerar nunca es aprobar. Se aprueba lo que es bueno, y se tolera lo que no es tan malo. Dicho de otra forma, es bueno tolerar ciertos males, pero que sean tolerables no significa que no sean males» $\mathrm{y}$, seguidamente, resalta su idea subrayando que «no es lo mismo tolerar que respetar. (...) se tolera lo malo —el mal menor-

Cfr. RUS RUFINO, S., «Antecedentes históricos de la idea moderna de tolerancia», en Educación en la tolerancia: I Jornada de educación cívica y democracia, 2006, Fundación Jiménez Abad de Estudios Parlamentarios y Estado Autonómico, pp. 4-6.

2 KAMEN, H., Nacimiento y desarrollo de la tolerancia en la Europa moderna, Madrid, 1987, p. 50.

3 Ibidem, pp. 109 y 110. 
mientras que se respeta lo bueno. En último término, el objeto propio del respeto es la persona y su dignidad. Sensu strictissimo, sólo la persona puede decirse que es digna de respeto» ${ }^{4}$.

Maravall señala que el vocablo «tolerar» es empleado con asiduidad en los documentos oficiales de la cancillería de los Reyes Católicos con el significado de «soportar o sufrir algo». Coetáneamente, Hernando del Pulgar, cronista de Isabel de Castilla, lo traduce como «dejar paso», «no oponerse severamente a algo» o como sinónimo de «disimular», expresión usada copiosamente en los siglos XVI y XVII. La tolerancia es un bien moral inferido del magisterio nazareno ${ }^{5}$, por lo que resulta refractario al catolicismo militante impuesto por la ortodoxia tridentina, que se convirtió en la ideología oficial de la Monarquía Hispánica, y que arrastró a la hoguera a los que pretendía liberarse del pesado yugo del credo oficial ${ }^{6}$.

En las Paradojas Racionales de López de Vega (1654) encontramos una de las primeras ocasiones en las que se utilizó en la España moderna el término «tolerancia» ${ }^{7}$ en su propio sentido etimológico: resignación ante la disidencia en orden a garantizar la convivencia; y de forma implícita aparece también en su vertiente positiva, que se fundamenta en el respeto a la dignidad del ser humano - «homo sacra res homini»(Séneca) $-y$, por tanto, se reconoce la libertad de conciencia como un atributo natural per se, desembarazado de las valoraciones que provoque su ejercicio e inmune a la tornadiza voluntad política.

«Cortesano. También mi espíritu ha sido siempre amante de la quietud y de la paz, y aun la vista de los que no las aman me molesta. Pero ya que no podemos conseguir lo que deseamos, valgámonos de la tolerancia, siquiera porque no digan que negándoles la virtud de la fortaleza venimos sus murmuradores a padecer la misma falta. Vivamos y dejemos vivir. Allá se lo hayan con su fiereza o su valor.

\section{$(\ldots)$}

Filósofo. (...) al hombre de juicio, como todo el mundo le es patria, todos sus habitadores le son también paisanos; soy francés, soy alemán, soy inglés, soy español, es lenguaje de gente vulgar. Las virtudes y vicios de unos y otros es lo que sólo nos debe hacer afectos o aversos» ${ }^{8}$.

4 BARRIO MAESTRE, J.M., «Tolerancia y cultura del diálogo», Revista española de pedagogía, $\mathrm{N}^{\circ}$ 224, 2003, pp. 135 y 137.

5 Mt 22, 21; Ga III, 28-28 y Rom 14, 1-13.

6 Cfr. MARAVALL, J.A., La oposición política bajo los Austrias, Madrid, 1972, pp. 135-137.

7 En 1614, la emplea Setanti en Centellas de varios conceptos. Cfr. BAE, tomo LXV, p. 528, citado en ibidem, p. 137.

8 LÓPEZ DE VEGA, A., Paradojas racionales escritas en forma de diálogo entre un cortesano y un filósofo, IV.

(C) UNED. Revista de Derecho Politico

N. ${ }^{\circ} 112$, septiembre-diciembre 2021, págs. 215-261 


\section{EL HUMANISMO CRISTIANO}

El humanismo cristiano es una corriente filosófica que hunde sus raíces en la patrística y en la Antigüedad grecolatina porque el pensamiento pagano aboca en el Evangelio: «Lo principal para Clemente de Alejandría es hacernos sentir la concordancia exquisita y profunda entre los griegos — poetas, filósofos, oradores: Homero, Hesíodo, Esquilo y Sóflocles- y el Antiguo y el Nuevo Testamento» ${ }^{9}$. Luis Vives, por su parte, era un entusiasta de la obra ciceroniana, en la que advirtió una penetración tributaria de la gracia divina: «(...) ninguna sabiduría humana, sin un beneficio e ilustración de Dios muy particular, ha podido conseguir y conocer las cosas que en esos libros están escritas» ${ }^{10}$.

«(...) Vives comparte con los sabios del Renacimiento — también con Servet— la idea de que las Sibilas - y Hermes, y los oráculos órficos- recibieron un anticipo de la definitiva revelación cristiana, idea que procede de San Agustín en el libro XVIII de La Ciudad de Dios, coincide con Cicerón en De divinatione, con Eusebio de Cesárea, historiador de la Iglesia antigua, y otros padres del Cristianismo» ${ }^{11}$.

El humanismo cristiano pretende la beatitud celestial mediante la armonización de la naturaleza herida por el pecado original y la gracia salvífica de Jesucristo, cifrada en la dilecta redención del Verbo encarnado que alumbra la eternidad: «El principio básico del Humanismo cristiano —a saber, que la naturaleza humana no está corrompida, sino que requiere, para florecer, la savia vitalizadora de la gracia- ilumina desde el principio la concepción de la comunidad humana; ésta tiene sus fundamentos en la Ley natural, grabada en la razón de todo hombre, y en la caridad, que paraliza el egoísmo animal» ${ }^{12}$.

El humanismo cristiano preconiza el irenismo religioso y la caridad. Reivindica un retorno a la prístina pureza evangélica, cuyo centro de gravedad es la preservación de la dignidad humana por medio de la dialéctica de la tolerancia y del amor al prójimo. Esta corriente de pensamiento es el parto de la inteligencia de algunos destacados filósofos medievales como Ramón Llull, «precursor del diálogo interreligioso, deseaba que se estableciese un Forum permanente de Debates, que no debería interrumpirse hasta conseguirse la unidad no sólo entre las tres religiones monoteístas sino también la de los griegos, nestorianos, jacobitas, albanos, rusos, armenios y

9 HERMANS, F., Historia doctrinal del humanismo cristiano, Valencia, 1962, p. 182.

10 Templo de las leyes. Prelección al Libro de las leyes de Cicerón (1519), citado por ALCALÁ GALVE, A., «El ideal humanista de la libertad de conciencia: Erasmo, Vives, Servet», en LÓPEZ VEGA, A. y SCHWARTZ GIRÓN, P. (eds.) Luis Vives. Humanista español en Europa (Semana Marañón 2006), Valencia, 2008, p. 211.

11 Ibidem, p. 211.

12 HERMANS, F., op. cit., p. 330. 
georgianos que en su tiempo se habían separado de la Iglesia romana» ${ }^{13}$; o Nicolás de Cusa, Marsilio Ficino y Pico de Mirándola, cuyo objetivo es la concordia o conciliación universal de los creyentes poniendo en valor «las verdades filosóficas compartidas por la humanidad, para lo cual se apoyaron con vigor en la herencia griega redescubierta y menos en los aspectos puramente dogmáticos de la religión» ${ }^{14}$ : el sincretismo religioso caracterizado por «la unión de las iglesias y de las sectas, no obstante sus divergencias, sobre la base de algunas verdades comunes, de algunos «artículos fundamentales» $»^{15}$.

« ¿Os parecería bien que (...) debatiésemos todos los días, y una vez por día, siguiendo las instrucciones que la Dama inteligencia nos mostró; y que nuestro debate durase hasta que los tres - judíos, cristianos y musulmanes - tuviésemos una sola fe y una ley, y hasta que lleguemos entre nosotros a una tal manera de honrar y de servirnos unos a los otros que produjese la concordia? Porque la guerra, el trabajo y la malevolencia, y el hacer daño y ultraje impiden que los hombres concuerden en una sola creencia» ${ }^{16}$.

La doctrina científica atribuye a Erasmo de Rotterdam —lumen mundi- el liderazgo del movimiento reformista — de complexión espiritualista- de la envilecida Iglesia católica medieval, abanderado por el humanismo cristiano, cuyo magisterio se proyecta sobre el horizonte europeo: «La Reforma alemana y el «siglo de las luces», la libre investigación de la Biblia y, por otra parte, las sátiras de un Rabelais o un Swift, las ideas europeas y el moderno humanismo..., todo esto son pensamientos nacidos de su pensamiento, pero no de su propia acción; en todas partes dio el primer empuje, en todas partes los movimientos fueron más allá de lo que él mismo había ido» ${ }^{17}$.

El príncipe de los humanistas «fue un hombre de transición pacífica, no de ruptura. Para el viejo mundo resultó un traidor, para el nuevo mundo un reaccionario» ${ }^{18}$. Este enconamiento hacia la figura de Erasmo resulta de su incomprendido pacifismo equidistante en la histórica encrucijada político-religioso concitada en las dietas imperiales de Worms (1521) y de Augsburgo (1530), a las que, pese a los insistentes requerimientos de mediación provenientes de las más altas dignidades europeas, declinó asistir. Su conspicua autoridad en la conciliación entre protestantes y católicos probablemente habría impedido la voladura de la unidad y la concordia cristiana y, por tanto, el fratricidio que asoló Europa.

13 JAULENT, E., «Fundamentos epistemológicos del diálogo luliano», Anuales del Seminario de Historia de la Filosofía, N'20, 2003, p. 34.

14 KAMEN, H., op. cit., p. 24.

15 LECLER, J., Historia de la tolerancia en el siglo de la reforma, Alcoy, 1969, pp. 152 y 154.

16 LLULL, R., Libro del gentil y de los tres sabios (1278), reflexión final de la obra.

17 ZWEIG, S., Erasmo de Rotterdam, Barcelona, 1986, p. 71.

18 MARINA, J.A., «Introducción», en ERASMO, Elogio de la locura o encomio de la estulticia, p.14, Barcelona, 1999, p. 16. 
La mundanidad de los curiales, la violencia contra los herejes y las adulteraciones escriturísticas de los escolásticos urgían una reforma integral de la Iglesia (in capite et in membris). Erasmo denuncia la censura teológica, las estériles sutilezas dogmáticas, el huero ceremonial litúrgico, las devociones externas, la impudicia monacal, eclesial e imperial en su magnum opus, Elogio de la Locura ${ }^{19}$; así como en otras obras que han alcanzado menor popularidad como Julio II, Silenos de Alcibíades o La guerra es dulce para quienes no la ban vivido.

¿Cómo es posible que se extraviara el dilecto magisterio de Jesucristo en la viciosa ética mundana? En el Capítulo VII de La guerra es dulce para quienes no la han vivido, Erasmo señala con precisión los dos hitos que jalonan el proceso de degradación espiritual del mensaje evangélico: la erudición bíblica empuñada para combatir las herejías medievales desembocó en la asunción teológica de la filosofía aristotélica «de forma tal que su autoridad es más venerable que la de Cristo. Efectivamente, si lo que dijo Cristo se adapta difícilmente a nuestra vida, está permitido deformarlo mediante una interpretación retorcida; en cambio se condena de inmediato a quien osa oponerse, aunque sea ligeramente, a los oráculos del estagirita. (...) Nos esforzamos por conciliar todos sus decretos con la doctrina de Cristo, esto es, por mezclar el agua con el fuego». Y en segundo término, la incorporación a la doctrina evangélica de ciertas disposiciones del Corpus Iuris Civilis, vigente en Occidente a partir del siglo XI gracias a su redescubrimiento y estudio por la Escuela boloñesa: «Hemos aceptado también algunas cosas de las leyes imperiales por la justicia que manifiestan y para que la concordia fuera mayor hemos interpretado torcidamente la doctrina evangélica adaptándola a ellas en la medida de lo posible. Ahora bien, estas leyes permiten repeler la fuerza mediante el uso de la fuerza y que cada uno intente hacer valer su derecho; aprueban el comercio, admiten la usura con tal de que sea moderada, alaban la guerra como una empresa insigne con tal que sea justa» ${ }^{20}$.

El breve viaje a Inglaterra emprendido en 1499 ahondó en su desengaño escolástico -Erasmo había sufrido la teología escotista durante su estancia parisina-, gracias a la amistad trabada con el humanista cristiano John Colet, que le inculcó «de una forma viva la realidad de una teología alternativa a la escotista, una teología de inserción escriturística que ampliaba el retorno humanista a la antigüedad de las letras, a las fuentes originales de la religión cristiana» ${ }^{21}$. En esta oportunidad también cuajó una relación amistosa con santo Tomás Moro, martirizado por no secundar el cisma anglicano de Enrique VIII, quien pregonó una tolerancia limitada en su inmortal Utopía (1516) puesto que, si bien reconocía la diversidad de cultos y se oponía a la coacción religiosa, negaba la libertad de conciencia a los ateos y a los materialistas descreídos del reino celestial porque eran creencias deletéreas para el bien común. Asimismo, defendió la represión contra las iglesias reformadas por socavar el orden

19 Cfr. Caps. LIII-LXI.

20 ERASMO, La guerra es dulce para quienes no la han vivido, VII, líneas 705-725.

21 GRANADA, M.A., «Estudio preliminar», en ERASMO, Escritos de crítica religiosa y política, Madrid, 2008, p. XIII. 
público y atentar contra la unidad de la fe cristiana, imprescindible para emprender la guerra justa contra el turco, invasor de la cristiandad.

En el Manual del caballero cristiano o Enchiridion (1504), Erasmo enuncia la filosofía de Cristo, fundada en la devotio moderna: un cristianismo caritativo, fundado en la pureza evangélica - «mira cómo se aman estos cristianos los unos a los otros» (Tertuliano)-; la espiritualidad: «La individualidad de cada ser humano comenzó a ser aceptada como valor fundamental y punto de partida de todo sistema de relaciones con Dios, con el mundo y con los demás hombres» ${ }^{22}$ y la tolerancia ${ }^{23}$ : «No quebrará la caña cascada ni apagará la mecha humeante, con fidelidad traerá justicia» ${ }^{24}$. El humanismo cristiano preconiza una relación íntima y personal con Dios, alentada por la savia nutricia de las enseñanzas nazarenas y petrinas. Rehúye, pues, el rigorismo judío, el artificio devocional romano y los dogmas escolásticos.

La médula de la reforma preconizada por Erasmo entrañaba una vuelta a los orígenes del cristianismo: «un evangelio sin dogmas y una religión de puro espíritu» ${ }^{25}$. Pretende recuperar las esencias evangélicas de las comunidades paleocristianas mediante la separación de la Iglesia y el Estado, cuyo hermanamiento fue el germen del fanatismo católico medieval ${ }^{26}$; la sustitución de la doctrina de la fe, anclada en los dogmas forjados en los concilios de la cristiandad, por una filosofía de Cristo: «una doctrina de conducta; el cristianismo no es para él sino un sinónimo de la moralidad alta y humana ${ }^{27}$ que apela contantemente a la conciencia - «lumen quod in te est ${ }^{28} »-\mathrm{y}$ a los deberes de la caridad con el prójimo ${ }^{29}: «(.$.$) la religión interior viva y sincera,$ el contacto directo con el espíritu de la Escritura, la imitación de Cristo mediante el ejercicio sincero y no ostentoso de las virtudes morales en el marco de las relaciones interhumanas, singularmente de la filantropía» ${ }^{30}$.

22 YANES CABRERA, C., «Antecedentes de una educación para la tolerancia en la Historia de la Educación española a través de alguno de los educadores más representativos», Revista Iberoamericana de Educación, Vol. 39, N4, p. 2

23 «Pues, en primer lugar, oigo que cuando os reunís como iglesia hay divisiones entre vosotros; y en parte lo creo. Porque es preciso que entre vosotros haya disensiones, para que se hagan manifiestos entre vosotros los que son aprobados» (1 ${ }^{\text {a }}$ Co 11:19).

24 Is $42: 3$

25 LECLER, J., op. cit., p. 173.

26 «La base de la intolerancia en la Edad Media fue la alianza entre la Iglesia y el Estado. Mientras la Iglesia predicaba el sometimiento resignado a los poderes terrenales, el Estado intervenía para erradicar la heterodoxia religiosa donde quiera que se produjera con objeto de preservar la unidad dogmática y social de la cristiandad» (KAMEN, H., op. cit., p. 16).

27 ZWEIG, S., op. cit., p. 86.

28 «(...) san Pablo considera también a la conciencia como la luz y la guía de toda la vida moral y religiosa y no sólo como el juez y el testigo de nuestros actos» (LECLER, J., op. cit., pp. 56 y 57).

29 «La caridad es paciente, servicial, no es envidiosa, no es jactanciosa, no se engríe; es decorosa; no busca el interés; no se irrita; no toma en cuenta el mal; no se alegra de la injusticia; se alegra con la verdad. Todo lo excusa. Todo lo cree: Todo lo espera. Todo lo soporta» (1 $1^{a}$ Cor $\left.13,4-7\right)$.

30 GRANADA, M.A., op. cit., pp. XVI y XVII. 
«Lo esencial de la filosofía cristiana consiste en saber que toda nuestra esperanza descansa en Dios, que nos concede gratuitamente sus dones por mediación de su Hijo. La muerte de Jesús nos rescata; el bautismo nos une a su cuerpo; muertos a los deseos de este mundo, debemos vivir conforme a sus enseñanzas y sus ejemplos, hacer bien a todos, y cuando nos sorprenda alguna adversidad, soportarla animosamente en la esperanza de la recompensa futura, reservada sin duda alguna a los hombres piadosos, cuando venga Cristo de nuevo. Debemos progresar en la virtud, pero sin atribuirnos ningún mérito, pues Dios es el dispensador de todo bien» ${ }^{31}$.

Este anhelo de inocencia evangélica predicado por Erasmo constituye el renacimiento del cristiano: el hombre nuevo redivivo debe ser un fiel epígono de Jesucristo, como lo fueron los primeros cristianos que practicaban clandestinamente su culto al Redentor en las catacumbas romanas. El renacer de la vida espiritual planteaba un agrio conflicto entre teólogos escolásticos y filólogos humanistas, porque exigía ineludiblemente el injerto de las disciplinas lingüísticas en la teología para acendrar las fuentes sacras del cristianismo ante la adulteración que había sufrido la Vulgata de san Jerónimo.

«Pretender que la teología es demasiado grande para plegarse a las leyes de la gramática y que todo el trabajo de la traducción depende de la inspiración del Espíritu Santo, es ciertamente otorgar a los teólogos una dignidad completamente nueva, pues sólo a ellos les estaría permitido expresarse bárbaramente (...) ¿Vamos a elevar nuestros propios errores hasta el Espíritu Santo y decir que él es su autor? Pero sea; los traductores han traducido bien. Ahora bien las traducciones se echan a perder (...) Sin embargo no está permitido, dicen, modificar absolutamente nada de las Sagradas Escrituras, pues no contienen ni un solo trazo que no tenga una fuerza secreta. Muy al contrario: igual que está prohibido alterar, es obligación de los sabios corregir con atención lo que ha sido alterado por ignorancia, con las precauciones y moderación debidas a todos los libros y en particular a los libros sagrados» ${ }^{32}$.

Erasmo ejerce su libertad de conciencia cuando emprende «la exploración de las fuentes del cristianismo, traduciendo nuevamente, como crítico de textos, filósofo y exégeta, los Evangelios del griego al latín (...)» ${ }^{33}$. Sin embargo, la aspiración erasmista era más ambiciosa: consciente de que el monopolio eclesial de la interpretación del magisterio de Cristo prostituía el mensaje celestial y confería un poder extraordinario a los curiales sobre las almas, era preciso reconocer la libertad religiosa de todos los creyentes para leer directamente la Biblia, para lo cual era preciso su traducción a las lenguas romances: "La vida de Cristo, tal como es referida en los Evangelios, no debe seguir siendo por más tiempo privilegio de frailes y curas, de la gente que sabe latín; todo el pueblo puede y debe participar en ella, el aldeano debe leerla detrás de

31 Carta de Erasmo a su amigo Juan Slecha (noviembre de 1519), citado por LECLER, J., op. cit., pp. 166 y 167.

32 GRANADA, M.A., op. cit., p. XVIII.

33 ZWEIG, S., op. cit., p. 87. 
su arado, el tejedor de su telar; la mujer tiene que poder transmitir a sus hijos este núcleo de todo el cristianismo» ${ }^{34}$.

El humanista holandés diseñó una propuesta de reforma de la iglesia romana que gravitaba sobre tres pilares: « $1^{\circ}$ sustituir la represión y la violencia por el espíritu cristiano de dulzura y de caridad; $2^{\circ}$ volver de nuevo a una fe más simple, desembarazada de las sutilezas y de los falsos intelectualismos de una teología decadente; $3^{\circ}$ restaurar seriamente la vida y las costumbres cristianas, sobre el modelo de la Iglesia primitiva, más rica en caridad que en artículos de fe» ${ }^{35}$.

«La Suma de nuestra religión es la paz y la concordia, lo que no se puede mantener más que con una condición: definir el número más pequeño posible de dogmas y en muchas cosas dejarlas al juicio propio de cada uno. Pues la oscuridad de muchas cuestiones es realmente inmensa. Por otra parte, constituye un mal ingénito en el espíritu de los hombres, según el cual cuando una cosa se ha puesto en discusión ya no saben volverse atrás... Ahora se apela al concilio ecuménico para que resuelva muchos problemas; se haría mejor remitiéndolos al día en que, el enigma y el espejo habiendo desaparecido, veamos a Dios cara a cara» ${ }^{36}$.

La Reforma protestante constituye un complejo fenómeno político-religioso erizado de confesiones heterogéneas - las reformas protestantes - que brotaron de las noventa y cinco tesis sobre las indulgencias, clavadas en la puerta de la Iglesia de Todos los Santos de Wittenberg en 1517 por el fanático fraile antisemita Martín Lutero. El dómine de la revolución nacionalista y antropocéntrica - «el hombre es la medida de todas las cosas» (Protágoras) - y sus aventajados discípulos —Zwinglio y Calvino- pronto remedaron a la Ramera de Babilonia y se divorciaron de la piadosa reforma erasmista, adoptando su propio ideario religioso cuyo objetivo era sujeción de la iglesia al poder político y «la escisión entre la gracia y la naturaleza, entre el orden natural y sobrenatural» por medio de la justificación por la fe (doctrina del servo arbitrio ${ }^{37}$ ) y la predestinación:

«Lo sobrenatural, la gracia, quedaba totalmente extrínseca al hombre, el cual ni siquiera tenía que preocuparse de cooperar con ella. El orden sobrenatural no comportaría ya una renovación profunda de la persona, sino una simple adjudicación de los méritos de Cristo hecha a este hombre sí y aquél no, según capricho del Dios predestinante. (...) La filiación divina, ganada por la Redención, era puro nombre. No se era hijo de Dios, sino sujeto de su Providencia, pero de una Providencia tal que bien

34 Ibidem, p. 87.

35 LECLER, J., op. cit., p. 172.

36 Carta de Erasmo a Juan Carondelet, arzobispo de Palermo (5 de enero de 1523), citado en ibidem, p. 169.

37 «La naturaleza humana había sido esencialmente corrompida y vulnerada por el pecado original; había que mirarla con el más negro pesimismo. Para proclamar la gran Reforma, la gran independencia religiosa del individuo, comenzaba por proclamarse la esencial falta de libertad y la consiguiente irresponsabilidad del hombre» (SÁNCHEZ-MARÍN, F.G., Humanismo natural y bumanismo cristiano, Madrid, 1954, pp. 25 y 26).

(C) UNED. Revista de Derecho Politico

N. ${ }^{\circ} 112$, septiembre-diciembre 2021, págs. 215-261 
pudiera llamarse también Fatalidad, por cuanto el hombre ninguna opción le cabía respecto de su destino eterno $»^{38}$.

La estrepitosa proclama liberal albergaba una sutil añagaza: Lutero predicaba la tolerancia religiosa por medio de la relación directa con Dios — sin sujeción a dogmas, autoridades ni magisterios eclesiales - y el reconocimiento del derecho a la libre interpretación de la Biblia por los creyentes (la teoría del sacerdocio universal), pero en realidad embozaba un ariete con el que abrir las puertas de las ciudades y perpetrar una revolución intolerante y homicida contra el discrepante de los nuevos dogmas protestantes, una vez que la acción evangelizadora — aprovechando la debilidad papista- lograse la conversión de la mayoría del territorio ${ }^{39}$. Esta trasfiguración violenta de la Reforma desencadenó siglo y medio de crudelísimas guerras religiosas que desangraron el Viejo Continente en orden a disputar la hegemonía católica sobre el orbe, pero la ausencia de unidad teológica dentro del protestantismo ${ }^{40}$ y la propia violencia desatada en el seno del movimiento reformista diluyeron cualquier pretensión supremacista.

La factura impagable de la barbarie protestante fueron miles de católicos quemados por las autoridades civiles de Alemania, Suiza, Francia e Inglaterra a causa de su herejía: interpretar la Biblia de manera diferente al oráculo de turno, paradójicamente convertido por su propia autoridad en supremo exégeta de la Palabra de Dios. Las masacres cainitas en Europa no pudieron ser encauzadas hacia la tolerancia por la vía del diálogo en los numerosos coloquios —especialmente Ratisbona (1541)- celebrados al más alto nivel teológico en Alemania y auspiciados por Carlos V. Tampoco contribuyó a tender puentes el encastillamiento dogmático de la Contrarreforma católica que se estaba fraguando en el Concilio de Trento. Finalmente, los debates doctrinales fueron suspendidos debido a la radicalidad de las disensiones, que no permitían albergar expectativas razonables de concluir con un acuerdo de mínimos, esto es, una serie de artículos de fe aceptados por católicos y protestantes en el marco del respeto a la discrepancia en los demás dogmas no esenciales para la salvación de las almas, lo que hubiese coadyuvado decisivamente a la reconciliación cristiana.

La Paz de Augsburgo de 1555 signó el fracaso político del Emperador, que durante décadas buscó infatigablemente la integración de los protestantes en una confederación cristiana que luchase contra el infiel musulmán: «(...) en el Renacimiento se rompe esa unidad de la conciencia cristiana y bajo el impulso juvenil y vigoroso de

38 Ibidem, p. 25.

39 «(...) tras haber pedido la libertad de palabra, la herejía nos la negará; tras haber pedido un templo y una cátedra, nos arrojará de todos los templos y de todas las cátedras» (MORO, T., Apology, XXVII, citado por HERMANS, F., op. cit., p. 377).

«El luteranismo rompió primero la unidad de la Iglesia, apartándose de Roma. Poco a poco la unidad dogmática fue rompiéndose como un cristal en las manos protestantes. Muy pronto la única unidad del protestantismo fue la negativa unidad del odio al Papa» (SÁNCHEZ-MARÍN, F.G., op. cit., p. 24). 
aquella etapa bulliciosa, anhelante, crédula y embriagada con su propia facundia, se despliega una serie de dualismos que el espíritu analítico de la época no sólo no intenta resolver en una unidad superior sino que, por el contrario, le lleva a complacerse en exaltar la esencial sustantividad de cada uno de los términos, a fin de enriquecer el cuadro de las dicotomías de la cultura ${ }^{41}$. Se impuso finalmente la práctica intolerante consolidada en los principados germanos y en las ciudades soberanas suizas: iglesias nacionales instituidas y controladas por una suerte de teocracia real, a la que estaban sujetos los súbditos sin otras alternativas para los infieles que la conversión o el exilio, con lo que se suturó de forma inescindible nacionalidad y religión.

Las consecuencias históricas del principio protestante cuius regno, eius religio fueron el fortalecimiento del absolutismo teocrático — desconocido en la tradición parlamentaria, municipalista y fuerista del medievo español y en la propia Monarquía Hispánica ${ }^{42}$-; una abisal grieta en la unidad de la cristiandad que no ha podido sellarse después de cinco siglos y el desarrollo del nacionalismo europeo que fragmentó el Viejo Continente en un nuevo ente político: el Estado-Nación.

El sabio holandés no fue un hombre de acción; fue un hombre de reflexión y de refinada expresión que observaba descorazonado la desfiguración de su ideario reformista y la tragedia europea: la deriva intransigente y violenta de las iglesias reformadas responsables de la fragmentación de la cristiandad. Sin embargo, debemos subrayar que Erasmo, junto con otros destacados discípulos como Moro, Vives, Furió Ceriol o Servet, defendieron la libertad religiosa en la atribulada Europa del Quinientos, cuya impronta doctrinal se hará patente en egregios filósofos iusracionalistas de la segunda mitad del siglo XVII como Spinoza, Puffendorf, Locke o Bayle.

\section{LOS ERASMISTAS ESPAÑOLES}

El erasmismo tuvo un gran predicamento en España durante el primer tercio del Quinientos: no sólo entre la intelectualidad patria, sino que su pensamiento coronó las cumbres áureas gozando de la protección real, inquisitorial y eclesial: «Es una paradoja histórica la floración de traducciones de Erasmo en el país de la Inquisición, en esa España donde la censura de los libros sería, unas cuantas décadas después, más severa que en ningún otro lugar» ${ }^{43}$. La protección erasmiana dispensada por el propio Emperador y su corte resultó fundamental para su arraigo hispánico y para conjurar los embates escolásticos perpetrados en la Conferencia de Valladolid de 1527, annus mirabilis del poder regio, encumbrado por la victoria de Pavía ante Francisco I y el saco de Roma. Sin embargo, la salida de España del Rey para atender los conflictos internaciones y los fallecimientos del Inquisidor General, Alfonso Manrique, y del

41 RÍOS, F. de los, Religión y Estado en la España del siglo XVI, México, 1957, pp. 33 y 34.

42 Cfr. JUDERÍAS, J., La leyenda negra de España, Madrid, 2014, pp. 136-141.

43 BATALLION, M., Erasmo y España. Estudios sobre la bistoria espiritual del siglo XVI, Madrid, 1995 , p. 314.

(C) UNED. Revista de Derecho Politico

N. ${ }^{\circ} 112$, septiembre-diciembre 2021, págs. 215-261 
cardenal arzobispo de Toledo, Alfonso III de Fonseca, dejaron expedito el camino para que la facción intransigente del academicismo español — Vitoria, Alonso de Córdoba o Vázquez de Oropesa - cabildeara en orden a que el Santo Oficio prohibiera las obras de Erasmo y persiguiera a sus prosélitos españoles, identificados con el movimiento iluminista: Juan de Vergara, María Cazalla, Miguel de Eguía, entre otros.

El maestro Nebrija comparte con Servet, Vives y Vergara «la actitud abierta, antiescolástica y antibárbara de aplicar técnicas humanistas a la mejor comprensión del texto y del mensaje tanto clásico como evangélico» ${ }^{44}$ y que fueron perseguidos por la Inquisición.

La libertad de filosofar a la que se había acostumbrado durante sus años de estudio en Bolonia propició que reprobara las crípticas logomaquias de la escolástica, la endémica ignorancia del latín y a los médicos, gramáticos, juristas y teólogos por su incapacidad para interpretar correctamente los textos clásicos, lo que le procuró no pocos antagonistas en la Universidad de Salamanca.

El padre de la gramática española había aplicado con éxito sus conocimientos filológicos y lingüísticos al derecho civil y a la medicina, corrigiendo sus yerros y desaciertos, por lo que decidió examinar las Sagradas Escrituras con el fin de acrisolarlas en orden a que recobraran su prístino esplendor.

Utilizó el método filológico para bruñir la Palabra de Cristo e iluminar «la gruta oscura» del conocimiento de la Biblia «que no tiene luz, sino de trecho en trecho, y de todo lo otro está envuelto en tinieblas, que ni por allí podemos bien saber qué quiere Dios de nosotros ni por el contrario de qué nos manda huir» ${ }^{45}$. Sin embargo, este trabajo fue dificultado en extremo por los escolásticos, refractarios a que «no sabiendo yo de Sagrada Escritura me atreviera, con la sola Gramática, a hablar de la que no conocía» ${ }^{46}$.

Nebrija personificó el primer enfrentamiento — de los múltiples que vería el siglo $\mathrm{XVI}$ - entre los polemistas de la escuela tomista, que se arrogaban el monopolio de la interpretación de la Biblia, y los escrituristas, partidarios del análisis y la traducción directa de los textos en sus lenguas originales (hebreo, griego y arameo), ya que permitían descubrir su significado genuino sin las distorsiones interesadas de los dogmáticos.

En 1505 tenía preparados para publicar unos comentarios que corregían alrededor de cincuenta pasajes de las Sagradas Escrituras —Prima Quinquagena —, pero al ser delatado por los dominicos, que dominaban el Santo Oficio, el Inquisidor General Deza le arrebató el manuscrito para que desistiera de escribir sobre ese tema. La

44 ALCALÁ GALVE, A., Literatura y ciencia ante la Inquisición española, Madrid, 2003, p. 19.

45 «Epístola del Maestro de Lebrija al Cardenal quando avisó, que en las interpretaciones de las Dicciones de la Biblia no mandasse seguir al Remigio sin que primero viesen su obra», editada por R.

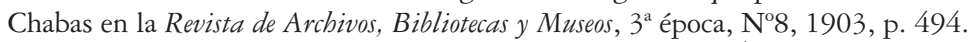

46 NEBRIJA, Apología, «Prólogo», citado por GARCÍA OLMEDO, F. Nebrija, debelador de la barbarie, Madrid, 1942, p. 128. 
Secunda decidió no publicarla ${ }^{47}$ y la Tertia logró hacerlo cuando el cardenal Cisneros, promotor de la Biblia políglota y que le apreciaba intelectualmente, gobernaba el Santo Oficio $(1516)^{48}$.

«Todas las vigilias, que durante estos diez años he consagrado a las sagradas letras, se han encaminado a limpiar algunos lugares de ellas que estaban viciadas por los copistas, o a descubrir los sentidos recónditos de ciertas palabras. Pero como una orden superior me tenía sellados los labios para que no hablase de estas cosas, en que había puesto tanto trabajo, me sometí a los superiores eclesiásticos, esperando que vendrían tiempos en que podría manifestar libremente mi parecer. Y he aquí que lo que nadie podía esperar, andando el tiempo llegó ese día. Porque, siendo tú Inquisidor General, puede decir cada uno lo que siente con toda libertad (...)» ${ }^{49}$.

En 1507, el Maestro publicó la Apología, obra de desagravio frente a las ofensas infligidas por los escolásticos. Constituye un audaz alegato en defensa de la libertad de expresión y una catilinaria contra los inquisidores de la conciencia, efectuados por una persona exhausta de vivir aherrojada en un país sectario que ahogaba su libertad:

«¿Qué sino será el mío que no sé pensar sino cosas difíciles, ni acometer sino arduas, ni publicar sino las que me dan más disgustos? Si me acomodara a la actitud de mis amigos y empleara mis vigilias en las fábulas y ficciones de los poetas, si me dedicara a escribir historias y, como dice el poeta, todo lo viera de color de rosa, me querrían bien, me alabarían, me darían mil parabienes. Pero como investigo en la tierra aquellas cosas cuyo conocimiento persevera en el cielo, me llaman temerario, sacrílego y falsario y no falta nada para que me hagan comparecer ante los jueces cargado de cadenas (...) ¿Qué hacer en un país donde se premia a los que corrompen las Sagradas Letras y, al contrario, los que corrigen lo defectuoso, restituyen lo falsificado y enmiendan lo falso y erróneo, se ven infamados y anatematizados y aun condenados a muerte indigna si tratan de defender su manera de pensar? No basta, no, que yo cautive mi entendimiento in obsequium Christi, en las cosas que la Iglesia me manda creer, sino que he de cautivarlo además en las que me son conocidas y manifiestas, más claras que la luz, y más verdaderas que la verdad, porque están fundadas, no en alucinaciones, opiniones, o conjeturas, sino en razones de diamante, en argumentos irrefragables, en demostraciones apodícticas. ¿He de decir a la fuerza que no sé lo que sé? ¿Qué esclavitud o qué poder es éste tan despótico? ¿Qué debo decir? Ni escribirlo encerrado entre cuatro paredes, ni murmurarlo en voz baja en un agujero de la pared, ni pensarlo a solas me permiten. ¿Y qué cosas son esas que ni pensarlas te permiten? Las que se refieren a la misma religión, en las cuales según el salmista, debe meditar

47 «Escribí dos comentarios sobre las sagradas letras: uno, que me arrancó a la fuerza el Obispo de Palencia, que después fue Arzobispo de Sevilla e Inquisidor General, no tanto para aprobarlo o condenarlo, cuanto para hacer que el autor dejara de escribir: y otro, que sustituí al primero y lo dejé para publicarlo en mejor ocasión. Porque aquel buen prelado no pretendía con todo esto sino que se borrasen hasta los vestigios de las dos lenguas [griego y hebreo] de las que depende nuestra religión, por los cuales pudiésemos en las cosas dudosas llegar a conocer con certidumbre la verdad» (ibidem, p. 128).

48 Sobre la estrecha relación entre Nebrija y Cisneros, véase ibidem, pp. 135 y ss.

49 NEBRIJA, Tertia Quinquagena, citado en ibidem, p. 138. 
el varón justo de día y de noche, die ac nocte (...) Díganme, por su vida, los que me censuran, ¿qué linaje de herejía es ésta? ¿Qué hay de herético, o que sepa a herejía, en ordenar las palabras y ponerlas como deben estar?» ${ }^{50}$

Las maquinaciones antierasmistas protagonizadas por las banderías reaccionarias propiciaron la persecución de los humanistas cristianos: Uceda, Tovar, Vergara, etc., de modo que, después de la muerte de Erasmo (1536), principian los «tiempos recios» (santa Teresa de Jesús) para la libertad en los campos espiritual y teológico: «[Los inquisidores] querían que nadie se aficionase a estas letras humanas por el peligro, como ellos pretenden, que en ellas hay: de que así como enmienda un humanista un lugar de Cicerón, así enmendará uno de la santa escritura; y diciendo mal de los comentadores de Aristóteles, hará lo mismo de los doctores de la Iglesia. Éstas y otras semejantes necedades me tienen desatinado, que me quitan las ganas de pasar adelante» ${ }^{51}$.

En 1533 Rodrigo Manrique, hijo del Inquisidor General Alfonso Manrique de Lara, escribió desde París una carta a Luis Vives sobre el encarcelamiento de Vergara, en la que relata el exánime estado de la libertad de palabra a causa del miedo a pensar inoculado en el alma humanista: "Cuando considero la distinción de su espíritu, su erudición superior y (lo que cuenta más) su conducta irreprochable, me cuesta mucho trabajo creer que se pueda hacer algún mal a este hombre excelente. Pero, reconociendo en esto la intervención de los calumniadores desvergonzadísimos, tiemblo, sobre todo si ha caído en manos de individuos indignos e incultos que odian a los hombres de valor, que creen llevar a cabo una buena obra, una obra piadosa, haciendo desaparecer a los sabios por una simple palabra, o por un chiste. Dices muy bien: nuestra patria es una tierra de envidia y soberbia; y puedes agregar: de barbarie. En efecto, cada vez resulta más evidente que ya nadie podrá cultivar medianamente las buenas letras en España sin que al punto se descubra en él un cúmulo de herejías, de errores, de taras judaicas. De tal manera es esto, que se ha impuesto silencio a los doctos; y a aquéllos que corrían al llamado de la erudición, se les ha inspirado, como tú dices un terror enorme» ${ }^{52}$.

El valenciano Luis Vives, «una de las cabezas más liberales y nobles que a la humanidad dio España» (Marañón), revolucionó la pedagogía europea desde Flandes, lugar al que se expatrió en su adolescencia a causa del semitismo familiar. Combatió con intemperancia a los discutidores de la Sorbona y trabó una sincera amistad con Erasmo y Tomás Moro. No obstante, compartía más puntos en común con el abogado inglés que con el pusilánime holandés: una reforma social, articulada en el caso de Vives mediante una política inclusiva de los desposeídos por medio del trabajo, desarrollada en su Tratado del socorro de los pobres (1526); mientras que, según Moro, la

50 NEBRIJA, Apología, «Prólogo», citado en ibidem, pp. 128 y 129.

51 Carta del médico humanista Alonso López Pinciano al historiador aragonés Jerónimo Zurita, citada por ALCALÁ GALVE, A., Literatura y ciencia..., op. cit., p. 237.

52 BATAILLON, M., op. cit., p. 490. 
plaga de mendigos que atormentaba Inglaterra sólo podía ser redimida a través de la devolución de las tierras de labranza, convertidas en improductivos pastizales, implementada mediante una limitación de la propiedad privada, encaminada al bien común; la frontal oposición al divorcio de Enrique VIII: «(...) el más intolerable criminal, una deshonra para la naturaleza humana, una mancha de sangre y grasa sobre la Historia de Inglaterra» (Dickens) y la guerra justa contra el turco porque el islam constituía una amenaza más grave que la reforma luterana, cuya neutralización debería encauzarse por la vía pacífica de un concilio «que diera satisfacción a la fe tradicional pero también a las justas exigencias de los luteranos $»^{53}$. Asimismo, fue un paladín de la libertad de filosofar en una Europa grávida de fanatismo religioso: «¿Cuál es la causa de que, habiendo tenido Atenas tantos sabios, y tantos Roma, y tantos nuestra religión cristiana, en nuestros tiempos haya tan pocos o ninguno? Pues porque en aquellas ciudades libres era permitido que fuesen libres las lenguas que arremetían contra la maldad y la hacían pedazos» ${ }^{54}$.

En la última carta que le escribió a Erasmo en 1534 tronó contra la persecución de los erasmistas españoles y los prelados ingleses que — como él— se oponían a la escisión de la Iglesia anglicana de Roma a causa del rechazo pontificio al divorcio de Enrique VIII: «Pasamos tiempos difíciles y no podemos hablar ni callar sin peligro. En España han sido detenidos Vergara y su hermano Tovar. En Inglaterra, los obispos de Rochester y Londres. Pido a Dios que te dé una vejez tranquila» 55 .

Esta atmósfera miasmática conjuraba cualquier disidencia teológica que pretendiera abrir alguna fisura en los dogmas del catolicismo. La mordaza de la libertad se aceró tras el Concilio de Trento y fue denunciada también por el arzobispo Carranza al final de sus días, después de haber sufrido un tempestuoso y dilatado proceso ante el Tribunal del Santo Oficio ${ }^{56}$ :

$$
\begin{aligned}
& \text { «Son hoy muy odiosas } \\
& \text { qualesquiera verdades } \\
& \text { y muy peligrosas } \\
& \text { las habilidades } \\
& \text { y las necedades } \\
& \text { se suelen pagar caro. } \\
& \text { El necio callando } \\
& \text { parece discreto } \\
& \text { y el sabio hablando } \\
& \text { se verá en aprieto; }
\end{aligned}
$$

Conviene hacerse
el hombre ya mudo,
y aun entontecerse
el que es más agudo
de tanta calumnia
como hay en hablar:
sólo una pajita
todo un monte prende
y toda palabrita
que el necio no entiende

53 ALCALÁ GALVE, A., «El ideal humanista de la libertad de conciencia: Erasmo, Vives y Servet», en LÓPEZ VEGA, A. y SCHWARTZ GIRÓN, P. (eds.), op. cit., p. 213.

54 VIVES, L, A la rebusca del sabio, citado en ibidem, p. 212.

55 Citado en ibidem, p. 219.

56 Cfr. TELLECHEA IDÍGORAS, J.I., El arzobispo Carranza y su tiempo, 2 vols., Madrid, 1968 y «El proceso del arzobispo Carranza por la Inquisición», Historia y Vida, No 3, 1970. 


$\begin{array}{ll}\text { Y será el efecto } & \text { gran fuego prende; } \\ \text { de su razonar } & \text { y, para se apagar, } \\ \text { acaescerle cosa } & \text { no hay otro remedio» } \\ \text { que aprende a callar. } & \text { si no es con callar» }\end{array}$

La adiposa lista de humanistas atormentados por la Inquisición a causa de mober la legua de otro modo ${ }^{58}$ no estaría completa si omitiésemos los procesos inquisitoriales incoados en 1572 a los hebraístas salmantinos: fray Luis de León, Gaspar de Grajal y Martín Martínez de Cantalapiedra, detonados por las delaciones de algunos docentes de la Universidad de Salamanca: «El origen y causa de esta denunciación que se hizo contra mí no fue el celo de fe ni de verdad, sino pasión y odio y deseo de destruirme con mentiras y calumnias. Constará esto si constare que los primeros autores de todo este movimiento fueron enemigos míos, e interesados en mi daño, y concertados y conjurados para él» ${ }^{59}$.

$$
\begin{aligned}
& \text { «Aquí la envidia y la mentira } \\
& \text { me tuvieron encerrado. } \\
& \text { Dichoso el humilde estado } \\
& \text { del sabio que se retira } \\
& \text { de aqueste mundo malvado, } \\
& \text { y con pobre mesa y casa } \\
& \text { en el campo deleitoso } \\
& \text { con solo Dios se compasa } \\
& \text { y a solas su vida pasa, } \\
& \text { ni enviadiado ni envidioso» } \\
& \quad \text { (fray Luis de León) }
\end{aligned}
$$

Tras superar los embates del Tribunal de la Fe, los profesores salmantinos concluyeron que el ejercicio de la libertad de cátedra conforme a su leal saber y entender era una temeridad que les situaba permanentemente en el filo de la navaja inquisitorial, por lo que se allanaron a la admonición paulina de la sobriedad en la sabiduría - «Non plus sapere quam oportet sapere, sed sapere ad sobrietatem ${ }^{60}$ - a pesar de que comportaba yugular su libre pensamiento y prosternarse ante la doctrina teológica oficial, sancionada por el poder civil y religioso.

Miguel Servet es un mártir de la libertad de expresión: «un símbolo de la lucha a favor de la libertad de conciencia, que sería recogido y ampliamente esgrimido en los siglos posteriores por los pensadores liberales del Siglo de las Luces para defender,

57 Citado por GIL FERNÁNDEZ, L., Panorama social del humanismo español (1500-1800), Madrid, 1997 , p. 452.

58 Dibujo grotesco del Álbum C de Goya (1803-1824).

59 ALCALÁ GALVE, A., Proceso inquisitorial de fray Luis de León: edición paleográfica, anotada y crítica, Salamanca, 1991, p. 327.

60 Rom 12:3. 
en diferentes grados, la necesidad de instaurar principios políticos y sociales de tolerancia en nuestras sociedades» ${ }^{61}$. El humanista aragonés defendió la libre interpretación de los textos bíblicos y se enfrentó a la pena capital impuesta a los herejes por los papistas y los reformadores protestantes: «Si hay que condenar a todo el que yerre en un punto particular, entonces habría que quemar a todos los mortales un millar de veces (...) si yo he tomado la palabra, por la razón que sea, ha sido para proclamar que me parece grave matar a los hombres bajo pretexto de que se equivocan en la interpretación de algún punto, puesto que sabemos que incluso los elegidos no están exentos de caer en el error» ${ }^{62}$.

Servet fue un osado defensor de la libertad de conciencia y de la libre discusión teológica en una Europa señoreada por el maniqueísmo religioso, la censura y la violencia institucional, en la que los librepensadores estaban condenados a una vida errabunda y azorada, hostigados por todas las banderías: "Todos me parecen tener parte de verdad y parte de error y cada cual espía el yerro ajeno, incapaz de ver el propio. Quiera Dios en su misericordia hacernos ver nuestros errores sin obstinación. Sería fácil juzgar, si a todos se les permitiera hablar en paz en la Iglesia, de modo que todos pudieran rivalizar en el don de la profecía y los que antes se sienten inspirados pudieran escuchar en silencio, como dice Pablo, a los que hablan luego cuando algo les es revelado. Pero hoy día todos rivalizan en el ansia de honores. Quiera el Señor destruir a los tiranos de la Iglesia. Amén» ${ }^{63}$.

El médico oscense fue perseguido por los papistas y los calvinistas a causa de la publicación de su libro Restitución del Cristianismo (1553), en el que impugnaba el dogma de la Santísima Trinidad (antitrinitarismo) y rehusaba el bautismo de los infantes (anabaptismo): «(...) si de verdad crees que el Papa es el Anticristo, debes tener también la certeza de que la Santísima Trinidad y el Bautismo, que forman parte de la doctrina papal, son dogmas del demonio» ${ }^{64}$.

Miguel Servet logró sustraerse a la férula inquisitorial, dirigida hacia él gracias a las maquinaciones calvinistas, fugándose de la cárcel de Viena del Delfinado en la que se encontraba recluido ${ }^{65}$, pero su errática huída le condujo a Ginebra, donde fue detenido en plena misa por los secuaces calvinistas. Fue salvajemente torturado en las mazmorras ginebrinas y condenado a morir en la hoguera junto a su libro maldito el 27 de octubre de 1553. Sin embargo, sus convicciones no lividecieron ante la

61 BACHES OPI, S., «Introducción a la vida y la obra de Sebastián Castellio», en CASTELLIO, S., Contra el libelo de Calvino, Villanueva de Sijena, 2009, p. 8.

62 Carta escrita en 1531 por Servet a Juan Ecolampadio, maestro suyo y reformador de Basilea (citado por MARTÍNEZ LAÍNEZ, F., Caminos abiertos por Miguel Servet, Ayuntamiento de Villanueva de Sijena, 1975, p. 42).

63 SERVET, M., «Dos diálogos sobre la Trinidad», en Obras Completas de Miguel Servet, vol. II, edición de Ángel Alcalá Galve, Universidad de Zaragoza, 2004, p. 634.

64 Carta de Servet a Calvino (1553), citada por ZWEIG, S., Castellio contra Calvino. Conciencia contra violencia, Barcelona, 2001, p.113.

65 A pesar de su huida del penal, el proceso inquisitorial continuó y fue quemado en efigie junto con los ejemplares de su libro en esta localidad francesa. 
oportunidad de salvar la vida por medio de una palinodia teológica: «Calvino mató a Servet por la verdad, porque no quiso mentir. En efecto, si Servet hubiera querido retractarse y hablar contra su conciencia, se habría librado, pero como dijo lo que pensaba, murió» ${ }^{66}$.

El humanista aragonés fue víctima de un fraudulento proceso inquisitivo que concluyó con su condena a muerte, impuesta por el Consejo de la ciudad a instancia de Calvino - el nuevo Moisés y sumo sacerdote del régimen hierocrático que funda en Ginebra, la Roma protestante - con el que pretendía encubrir un asesinato que proyectaba ejecutar desde que Servet le comunicó la primicia de la publicación de su libro ${ }^{67}$ : «Servet me ha escrito recientemente y ha adjuntado a su carta un grueso volumen con sus delirios, asegurando con increíble petulancia que en él habría de leer cosas sorprendentes. Declara estar dispuesto a venir aquí en caso de que yo lo desee...Pero no quiero pronunciarme sobre ello: pues si viniera, en tanto tenga aún algo de influencia en esta ciudad, no podría permitir que la abandonara con vida» ${ }^{68}$.

Esta no fue la primera atrocidad perpetrada por el protestantismo en Europa, ni tampoco el bautismo de sangre de Calvino. La Iglesia reformada fracasó en su objetivo de unidad frente al catolicismo romano en orden a disputarle la hegemonía religiosa europea. En efecto, la ardorosamente proclamada libertad de conciencia, injertada por el luteranismo en el robusto tronco de la cristiandad, germinó en una violenta floración confesional, cuyo fruto amargo fue la atomización y nacionalización del fenómeno protestante. Empero, no debemos preterir que la revolución luterana constituye un jalón en la histórica lucha por la libertad: «La Reforma en el siglo Xvi fragmentó la unidad religiosa de la Edad Media y condujo al pluralismo religioso, con todas sus consecuencias para los siglos posteriores. Lo que a su vez propició pluralismos de otros tipos, que acabaron convirtiéndose en un rasgo permanente de la cultura a finales del siglo XVIII» ${ }^{69}$.

«Establecer la regla de que cada hombre interpreta la palabra de Dios tal como la Biblia la expresa, y que nadie puede imponer su propia interpretación a otro, fue hacer de la libertad e igualdad individuales no sólo la base de la sociedad, sino también la expresión de la voluntad divina. La división de la cristiandad en múltiples religiones — católica, luterana, calvinista, anglicana, amén de las múltiples rivalidades entre sectas protestantes-, destruyó la idea de una verdad única y absoluta que se imponía a todos por su misma evidencia. Los conflictos religiosos hicieron derramar mucha sangre, provocaron muchas destrucciones, engendraron múltiples sufrimientos y horrores; sin embargo, también contribuyeron a desarrollar la idea de la coexistencia

CASTELLIO, S., op. cit., $\$ 91$.

67 Sobre la relación entre Servet y Calvino, así como todos los factores que rodearon la condena a muerte de Servet, véase ZWEIG, S., Castellio contra Calvino..., op. cit., pp. 104-151.

68 Carta de Calvino a su esbirro Farel (1553), citado en ibidem, p. 113.

69 RAWLS, J., El liberalismo político, Barcelona, 1996, p. 18. 
necesaria entre doctrinas opuestas. El pluralismo religioso aceleró el nacimiento del pluralismo político» ${ }^{70}$.

Los padres reformistas pronto arrumbaron los beatíficos fundamentos sobre los que pretendían erigir la Nueva Iglesia Evangélica e hicieron propia la violencia de cuño papista como instrumento para imponer la unidad religiosa sobre los principados y las ciudades soberanas, a pesar de que había sido reprobada por los próceres del protestantismo: Lutero, Zwinglio, Melanchton y hasta el propio Calvino tronaron en sus balbuceos públicos contra el estrangulamiento de la libertad espiritual perpetrado por la Iglesia romana. En efecto, «desde las costas españolas hasta el mar del Norte y las Islas Británicas, incontables herejes arden por esa misma época a mayor gloria de Cristo. En nombre de las distintas iglesias y sectas que se consideran las únicas verdades, miles y miles de hombres indefensos son vejados, quemados, decapitados, estrangulados o ahogados en el patíbulo».

«De un salto, [Calvino] da alcance a la Iglesia, que, en su honor y con todo, estuvo dudando más de mil años antes de quemar vivo a un hombre por una interpretación caprichosa en cuestiones de fe cristiana. Calvino, sin embargo, con este acto deleznable de su tiranía de espíritu, deshonra la Reforma ya en la segunda década de su gobierno. Desde el punto de vista moral, su acción es quizás más abominable que todos los crímenes de Torquemada, pues cuando la Iglesia católica expulsa un hereje de su comunidad y lo entrega a un tribunal de este mundo, en absoluto considera que con ello lleva a cabo una acción de odio personal, sino un acto de purificación, la salvación hacia Dios, desligando el alma inmortal de su cuerpo terreno y pecador ${ }^{71}$.

El asesinato de Servet fue un aldabonazo en las filas reformistas «que marcó el punto de partida de la controversia de la tolerancia en el Protestantismo» ${ }^{72}$ y desató una estéril indignación en exiguos círculos protestantes del norte de Europa: «(...) callan y siguen callados, los humanistas, los clérigos, los sabios. Unos, porque les repugnan los altercados en voz alta. Otros, por miedo a que se les considere también sospechosos de herejía si no ensalzan hipócritamente la ejecución de Servet como un acto loable» ${ }^{73}$. Del reducido grupo de audaces humanistas que reaccionaron frente a la muerte de Servet, destacaron sobremanera los alegatos en favor de la tolerancia del francés Sebastián Castellio.

Castellio arrostró con un prodigioso valor el régimen del terror calvinista. Empuñó su pluma de bronce para fustigar el execrable acto perpetrado en nombre de Dios por el tirano ginebrino. Su obra, Contra el libelo de Calvino (1554), fue escrita para censurar el intemperante libro de Calvino, Defensa de la fe ortodoxa sobre la sagrada

\footnotetext{
DUVERGER, M., Las dos caras de Occidente, Madrid, 1972, p. 40.

ZWEIG, S., Castellio contra Calvino..., op. cit., pp. 153 y 154.

BACHES OPI, S., «Introducción a la vida y la obra de Sebastián Castellio», en CASTELLIO,

73 ZWEIG, S., Castellio contra Calvino..., op. cit., p. 162.
} S., op. cit., p. 8. 
Trinidad, contra los prodigiosos errores del español Miguel Servet, con el que su soberbia teológica pretendía silenciar las tímidas críticas de algunos humanistas franceses e italianos sobre el juicio y la condena del teólogo aragonés.

Contra el libelo de Calvino constituye un inmortal ensayo apologético de la libertad de conciencia y de expresión. Castellion refutó mediante argumentos diamantinos - la separación Iglesia-Estado; la prohibición eclesial de las armas carnales; la limitación de la jurisdicción de la espada a los delitos comunes, la jurisdicción de la palabra en cuestiones de fe (tolerancia) - la infame condena a muerte de Servet por ejercitar su libertad de expresión en materia teológica: «Pero matar a un hombre no es defender una doctrina, es matar a un hombre. Cuando los ginebrinos ejecutaron a Servet, no defendieron una doctrina, mataron un hombre. Defender la doctrina no es propio del magistrado (qué tiene que ver la espada con la doctrina) sino del doctor. Sin embargo, defender al doctor es propio de magistrado, así como defender de la injusticia al agricultor, al artesano, al médico y a cualquier otro. Por eso, si Servet hubiera querido matar a Calvino, el magistrado habría defendido a Calvino con toda justicia. Pero, como Servet luchaba con argumentos y escritos, tenía que haber sido refutado con argumentos y escritos» ${ }^{74}$.

«(...) del mismo modo que los Apóstoles castigaron con su arma, esto es, con la palabra, a los que consideraron culpables según la jurisdicción de la palabra, y esto a causa de los pecados que atañen a las palabras y a la doctrina, así debe el magistrado castigar con su arma, esto es, con la espada, a los que considere culpables según la jurisdicción de la espada, y eso a causa de las faltas sobre las que la espada ejerce justicia. Y del mismo modo que Pedro no habría podido castigar con la palabra a un asesino, sino que lo habría entregado al magistrado, así el magistrado no puede castigar con el hierro al hipócrita, al hereje o al mentiroso (pues no tiene competencia para aplicar a esto Ley ninguna), sino que, para castigarlos, debe entregarlos a los pastores. De lo contrario se mezclarán los asuntos sagrados con los profanos» ${ }^{75}$.

Los brotes protestantes surgidos en Valladolid y Sevilla en la década de los cincuenta fueron reducidos a cenizas en los autos de fe celebrados entre 1559 y 1562. Los encartados por pertenecer a las iglesias reformadas utilizaban como estrategia en los procesos inquisitoriales la máscara de Erasmo (Batallion) «con la que trataban de enmascararse o enturbiar su declaración invocando la figura y la obra de Erasmo de Rótterdam, quien a pesar de los severos escrutinios teológicos y la interdicción o condena de algunas de sus obras, se mantuvo siempre dentro de la Iglesia de Roma y combatió públicamente a Lutero» ${ }^{76}$. Los reducidos conciliábulos luteranos fueron sobredimensionados deliberadamente por el Inquisidor General Valdés —caído en

\footnotetext{
74 CASTELLIO, S., op. cit., $\$ 77$.

Ibidem, $\$ 91$.

PÉREZ ESCOHOTADO, J., «Prólogo», en DELIBES, M., El hereje, Madrid, 2018, p. 40.
} 
desgracia ${ }^{77}$ - para encarecer el rigorismo y el celo inquisitorial contra la herejía; de esta forma pudo recobrar el afecto del mortificado Emperador ${ }^{78}$, que creía estar presenciando la reedición de las revueltas protestantes que habían fracturado la unidad religiosa del Sacro Imperio Romano Germánico, cuando en realidad jamás hubo en España grupúsculos heterodoxos lo suficientemente numerosos y dinámicos —unas ochocientas personas fueron procesadas ${ }^{79}$ - como para que entrañaran un riesgo para la religión oficial.

Los isidros, cenáculo formado por una docena de jerónimos del monasterio de San Isidoro del Campo, situado en el entorno monumental de Santiponce (Sevilla), constituían una célula luterana dispuesta a replicarse, pero a mediados del siglo XVI tuvieron que exiliarse a los países protestantes del norte de Europa para huir de las garras inquisitoriales por sus prácticas y enseñanzas evangélicas ${ }^{80}$. Aunque es controvertido en la historiografía, parece ser que dos de sus miembros más destacados, Casiodoro de la Reina y Antonio del Corro escribieron al alimón la obra titulada Artes de la Inquisión española, publicada en 1567 bajo el pseudónimo de Reginaldo González Montado en la ciudad alemana de Heildelbeg, en la que exponen con elocuencia las ominosas prácticas del Santo Oficio al objeto de que las abominaciones del catolicismo tridentino contribuyeran a denigrar la grandeza y dignidad de España.

El erasmista sevillano Casiodoro de la Reina consideraba que el cristianismo tiene una dimensión más moral y espiritual que dogmática, de modo que de la exégesis de la Biblia sólo se podían inferir un reducido número de verdades reveladas irrefragables. Así pues, el resto eran adiáforas: cuestiones indiferentes, debatibles, meramente opinables, por lo que la caridad cristiana impedía violentar a una persona por ejercer en este ámbito de lo indiferente su libertad de conciencia: «(...) hay errores que de ningún modo deben tolerarse [dogmas impíos y nuevos] y otros que pueden y, en efecto, deben tolerarse sin ninguna ruptura de la piedad entre hermanos, puesto que todos somos sabios por igual (...)» ${ }^{81}$. Estos últimos «no son perjudiciales a la común Fe y la Cristiana Caridad los sabe excusar y sufrir y cuando la oportunidad se ofrece, enmendarlos con toda suavidad ${ }^{82}$; pero respecto a los yerros inadmisibles no procedía en ningún caso la hoguera ni cualquier otro tipo de castigo físico, como aplicaba la Inquisición a los herejes, sino que, al igual que sostenía Castellion, debían usarse las

77 La indisposición de Valdés con el monarca se debió a que en su condición de arzobispo de Sevilla, canonjía notoriamente lucrativa, se negó a prestar a la Corona 150.000 ducados en 1557 (ORELLA UNZUÉ, J.L., «Erasmo en España y Vives en Europa. De adalides de la ortodoxia al ostracismo por su heterodoxia» en LÓPEZ VEGA, A. y SCHWARTZ GIRÓN, P. (eds.), op. cit., p. 188).

78 Ibidem, p. 188.

79 MORENO, D., Casiodoro de la Reina. Libertad y tolerancia en la Europa del siglo XVI, Sevilla, 2018, p. 64.

80 Cfr. Ibidem, pp. 21-81.

81 REINA, C., Comentario al Evangelio de San Juan, traducción de Francisco Ruiz de Pablos, edición de Emilio Monjo Bellido, Sevilla, 2009, pp. 67 y 68.

82 REINA, C., «Amonestación del intérprete de los Sacros Libros al Lector..., en Biblia del Oso, VI. 
armas espirituales: «las censuras eclesiales, el apartamento de la comunidad [excomunión] o la prohibición de participar en la Cena» ${ }^{83}$.

\section{LA IMPRONTA HUMANISTA EN LA COLONIZACIÓN AMERICANA}

Resultan injustificables los actos de barbarie cometidos en la conquista espiritual de las civilizaciones precolombinas, enmarcada en el proyecto de la Universitas Christiana: «Sería necedad e ignorancia (...) negar que hubo atropellos de los débiles por los fuertes; crueldades, algunas que revuelven el alma y aun el estómago; y quien se empeñe en lo contrario, mal servicio prestará a España: los españoles, hombres fueron, no ángeles y flaquezas humanas aparecen a modo de borras en el magnífico tapiz de sus hazañosos hechos» ${ }^{84}$. Sin embargo, también es cierto que el catolicismo no ostentó el monopolio de la fuerza en las otras guerras de religión que se prodigaron en Europa hasta la Paz de Westfalia (1648). Las diferentes confesiones religiosas, germinadas al calor de la Reforma protestante, fueron campeonas de la intolerancia y del dogmatismo más acendrado y se sirvieron de la violencia para uncir las conciencias bajo su credo: «No existía siquiera entonces la idea de la tolerancia civil o religiosa, ninguna nación, ni entre las fieles, ni entre las infieles; nadie reconocía el derecho al libre examen, ni entre los tradicionalistas ni entre los novadores: pensando igualmente que era justo quemar a sus contrarios, el célebre inquisidor general de Felipe II, don Fernando Valdés y el heresiarca Calvino» ${ }^{85}$.

En el marco académico de la Escuela Española de Derecho Natural y de Gentes tuvieron lugar agudos debates sobre la naturaleza humana y los derechos de los indios, la guerra justa y los títulos legítimos del dominio de España sobre las Indias Occidentales. En relación con esta última cuestión, había tres opiniones fundamentales: «1. ${ }^{a}$ La de los reyes y de los consejeros del reino, desde los días del descubrimiento, que tomaban la bula de Alejandro VI, de 4 de mayo de 1493, como título único, interpretada plena y rectamente como donación de las tierras descubiertas bajo precepto de evangelización subsecuente. 2. ${ }^{a}$ La de los dominicos rigoristas y de Las Casas, tomando la bula también como título único, pero interpretada en sentido restringido, como simple encargo para propagar el Evangelio, sin derecho alguno de guerra de conquista. 3. ${ }^{a}$ La de Vitoria y los dominicos posteriores dando preferencia a los títulos naturales humanos, en general, junto a los cuales se sitúa el título divino de la religión» ${ }^{86}$.

83 MORENO, D., op. cit., p. 205.

84 BAYLE, C., España en Indias, Barcelona, 1939, p. 30.

85 CÁNOVAS DEL CASTILlO, A., Casa de Austria, Barcelona, 1971, p. 49.

86 MENÉNDEZ PIDAL, R., El P. Las Casas y Vitoria con otros temas de los siglos XVI y XVII, Madrid, 1958, pp. 18 y 19. 
Dentro del área de influencia doctrinal de los Magni Hispani, destaca uno de los pioneros de la tolerancia en nuestro país: el misionero dominico Bartolomé de las Casas. La longeva y azarosa vida peregrina de este fraile converso sevillano —apóstol de los indios - se caracterizó por una permanente lucha en favor de los aborígenes americanos, «sus dulces ovejas»: «Todas estas universas e infinitas gentes a toto genero crio Dios las mas simples, sin maldades ni dobleces; obedientissimas: fidelissimas a sus señores naturales: e a los christianos a quien sirven: mas humildes, mas pacientes, mas pacificas e quietas: sin renzillas ni bollicios, no rixosos, no querulosos, sin rancores, sin odios, sin dessear venganças que hay en el mundo $(. ..){ }^{87}$.

El enfrentamiento de Las Casas contra el orden establecido tuvo una doble dimensión, a saber, práctica, liderada en el Nuevo Mundo frente a conquistadores y colonizadores y en España ante el Emperador y el Consejo de Indias; y dialéctica, plasmada en su ingente bibliografía en la que recoge el «descubrimiento en los indios de la dignidad de la persona humana» ${ }^{88}$, de la que derivó sus derechos inherentes (igualdad y libertad ${ }^{89}$ ): «Desde el principio del género humano, todos los hombres, todas las tierras y todas las otras cosas, por derecho natural y de gentes fueron libres y alodiales, o sea francas y no sujetas a servidumbre. Porque desde el origen de la naturaleza racional todos los seres humanos nacían libres. Puesto que siendo todos los hombres de igual naturaleza, no hizo Dios a un hombre siervo, sino que a todos concedió idéntica libertad (...) la libertad es un derecho inherente al hombre necesariamente y desde el principio de la naturaleza racional, y es por eso de derecho natural, como se dice en el Decreto [Graciano]: «existe idéntica libertad para todos»» ${ }^{90}$.

La bula Inter caetera, promulgada por el valenciano Alejandro VI, en 1493, fue el título jurídico argüido por España para emprender la última Cruzada: la conquista militar de las Indias Occidentales para su evangelización e incorporación patrimonial al Imperio español: «(...) sí se debe señalar la inaudita aportación del «Descubrimiento» al poderío español, los horizontes que abrió, como por milagro, a la expansión de un pueblo ya penetrado de su superioridad racial, de su eminencia espiritual y de la fuerza de sus armas, que en adelante también se considerará investido de una misión divina» ${ }^{91}$. Conviene subrayar, no obstante, que el descubrimiento del continente americano fue una magna empresa impulsada por el bizarro pueblo español, no de la Corona, inmersa en sus preocupaciones europeas: las costosas expediciones, integradas por grupos heterogéneos, se sufragaban con caudales privados sobre la base jurídica

87 LAS CASAS, B. de, Brevísima relación de la destrucción de las Indias, I.

88 CASTAÑEDA, P., «El pensamiento de Bartolomé de las Casas», Cuadernos salmantinos de filosofía, N ${ }^{\circ} X X X$, Universidad Pontificia de Salamanca, 2003, p. 673.

89 «Las Casas tenía dos ideas muy claras: que la libertad es, después de la vida, la cosa más preciada del mundo; y que la esclavitud va contra la Ley natural, porque atenta a la libertad. Por eso lucha contra ella y contra la guerra que priva a los indios de libertad» (ibidem, p. 674).

90 LAS CASAS, B. de, De regia potestate, pp. 15-17, citado por MARTÍNEZ MORÁN, N., «Aportaciones de la Escuela de Salamanca al reconocimiento de los derechos humanos», Cuadernos salmantinos de filosofía, NoXXX, 2003, p. 502.

91 PIÉTRI, F., La España del Siglo de Oro, Madrid, 1960, p. 91. 
de las capitulaciones, firmadas con el poder real, en orden a regular el reparto de las riquezas del Nuevo Mundo. Este régimen singular que favorecía los abusos y el propósito evangelizador socavaron las civilizaciones precolombinas y redujeron las poblaciones indígenas a la condición bestial durante la primera hora de la colonización, con el respaldo doctrinal de Pedro Mártir y de Sepúlveda.

La teoría filosófico-teológica de Juan Ginés de Sepúlveda gravita sobre tres puntales, a saber, la doctrina aristotélica sobre la esclavitud: «el derecho natural a la guerra contra el indio en virtud de su naturaleza inferior o de su precario rango humano»; la tradición agustiniana y tomista: «la Guerra Santa de conversión contra los gentiles» y la Guerra de Salvación —mesianismo hispánico—, redentora de las viciosas almas indianas ${ }^{92}:$ "Y sometidos así los infieles habrán de abstenerse de sus nefandos crímenes, y con el trato de los cristianos y sus justas, pías y religiosas advertencias, volverán a la santidad de espíritu y a la probidad de costumbres, y recibirán gustosos la verdadera religión con inmenso beneficio suyo, que los llevará a la salvación eterna. No es pues, la sola infidelidad la causa de esta guerra justísima contra los bárbaros, sino sus nefandas liviandades, sus prodigiosos sacrificios de víctimas humanas, las extremas injurias que hacían á muchos inocentes, los horribles banquetes de cuerpos humanos, el culto impío de los ídolos (...) Por muchas causas, pues, y muy graves, están obligados estos bárbaros á recibir el imperio de los españoles conforme á la Ley de naturaleza, y á ellos ha de serles todavía más provechoso que á los españoles, porque la virtud, la humanidad y la verdadera religión son más preciosas que el oro y que la plata. Y si rehúsan nuestro imperio, podrán ser compelidos por las armas á aceptarle, y será esta guerra justa por Ley de naturaleza» ${ }^{93}$.

El racionalismo de Francisco de Vitoria se opone al aristotelismo de Sepúlveda (la esclavitud natural del indio), a la utopía lascasiana del buen salvaje (la bondad innata del indígena) y a la doctrina medieval de la plenitudo potestatis, en virtud de la cual el papa era el Señor del orbe y el emperador y los reyes autoridades subalternas que ejercían por delegación la potestad civil. El poder temporal del pontífice debía limitarse a una potestas indirecta in temporalibus y específicamente sobre la grey cristiana, de modo que los españoles no estaban legitimados para forzar la conversión de los infieles americanos: "Aunque la fe haya sido anunciada a los bárbaros de un modo racional y suficiente y éstos no la hayan querido recibir, no es lícito, por esta razón, hacerles la guerra ni despojarlos de sus bienes» ${ }^{94}$. La misma proposición teológica mantiene Suárez: «(...) un hombre privado no puede obligar o castigar a otro también privado, ni un rey cristiano a otro rey cristiano, ni un rey infiel a otro pagano, tampoco la república de los infieles, que es soberana en su orden, podrá ser castigada por la

92 SUBIRATS, E., El continente vacío. La conquista del Nuevo Mundo y la conciencia moderna, Madrid, 1994 , p. 71.

93 SEPÚlVEDA, J. G. de, Tratado sobre las justas causas de la guerra, México, 1996, pp. 133-135.

94 VITORIA, F. de, Relecciones sobre los indios, II, 15. 
Iglesia a causa de sus crímenes, aunque vayan contra la razón natural. Tampoco podrán, pues, ser obligados a abandonar la idolatría y otros ritos semejantes» ${ }^{95}$.

Vitoria es el padre del derecho internacional por haber construido en sus Relecciones sobre los indios la teoría de la igualdad de los pueblos del mundo sobre la base de la solidaridad (interdependencia), la sociabilidad: «el ius communicationes y el ius commercii, que no comprende a sus ojos exclusivamente el intercambio de objetos materiales sino el intercambio de ideas» ${ }^{96}$, lo cual implica el reconocimiento del pluralismo; y la soberanía territorial, de manera que rechaza el axioma secular de una potestad suprema universal que ejerza una autoridad omnímoda sobre la tierra ${ }^{97}$.

El dominico salmantino comparte con Sepúlveda algunos de los «títulos legítimos e idóneos, por los que pudieron los bárbaros venir a poder de los españoles», de los cuáles cuatro están fundados en fines temporales y son, por tanto, puramente modernos: a) «la sociedad natural y la comunicación», con el que se garantiza el comercio, la libre circulación y residencia así como el derecho a ocupar las res nullius en el Nuevo Mundo; b) «la tiranía de los señores de los bárbaros o el carácter inhumano de las leyes que entre ellos imperen en daño de los inocentes»; c) «razones de amistad y alianza» y d) «la verdadera y voluntaria elección». En las otras tres causas legítimas, radicadas en la religión, apreciamos los resabios de la tradición medieval: a) «la propagación de la fe cristiana»; b) la violencia contra los convertidos al cristianismo y c) la deposición de los señores infieles cuando la mayoría profese la religión de Cristo. Finalmente, Vitoria apunta otro título que "podría, no ciertamente afirmarse, pero sí discutirse, considerando lo que pueda tener de legítimo»: la incapacidad del indio para gobernarse ${ }^{98}$.

La intelectualidad española remedó la injuria a la Naturaleza perpetrada por griegos y romanos en la Antigüedad, «pensando que para derramar la abundancia de sus dones buscó límites de montañas, ríos y mares, como si el poder divino estuviera limitado por los lugares, y dondequiera que nazca el hombre no brotaran también las virtudes que el hombre recibió por la benignidad divina, y no por merced del lugar» ${ }^{99}$. En efecto, los humanistas peninsulares definieron a los nativos americanos como «homúnculos» (Sepúlveda) ${ }^{100}$; «esclavos» $\left(\right.$ Soto ${ }^{101}$; «dementes» $(\text { Vitoria })^{102}$; «peores que locos, sin dominio sobre su propia vida» (Suárez) ${ }^{103}$; «malos y bestias» (Vasco de Quiroga) ${ }^{104}$ y «demonios» (los Doce Apóstoles franciscanos de

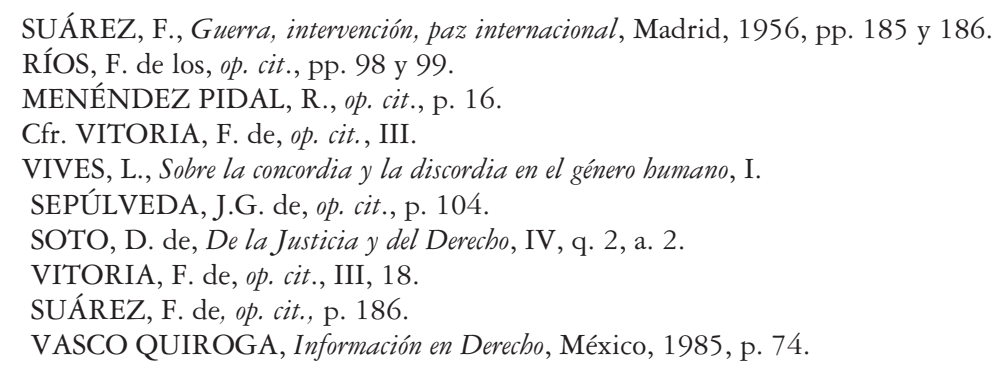


Nueva España $)^{105}$. El fundamento de estos estigmas radicaba, por una parte, en que los indios eran acerbos ofensores del Supremo Hacedor, responsables de abyectos pecados: sodomía, idolatría, oblaciones humanas, antropofagia, acidia, lascivia y perfidia y, por otra, en que eran seres inferiores privados de razón y, por tanto, incapaces de gobernarse a sí mismos. Así pues, «la guerra es definida como castigo; la destrucción de sus culturas, símbolos o formas de vida elevada a principio de libertad trascendente; su inferioridad natural justificaba la esclavitud como redención, incluso como liberación; el dolor y la muerte, el sufrimiento del castigo y del trabajo se convirtió, a su vez, en un medio expiatorio y camino de cristiana perfección a partir de su satánica forma de vida» ${ }^{106}$.

«Los hombres de Tierra Firme comen carne humana y son sodomíticos más que generación alguna; ninguna justicia hai entre ellos: andan desnudos, no tienen honor ni vergüenza: son como asnos abobados, alocados, insensatos: no tienen en nada matarse ni matar: no guardan verdad sino es en su provecho. Son inconscientes, no saben qué cosa sea consejo; son ingratos y amigos de novedades. Précianse de borrachos, tienen vinos de diversas hierbas, frutas, raíces y grano. Emborráchanse también con humo y con ciertas hierbas que los sacan de seso. Son bestiales en los vicios; ninguna obediencia ni cortesía tienen mozos a viejos, hijos a padres. Son traidores, crueles, vengativos que nunca perdonan: inimicísimos de religión, haraganes, ladrones, mentirosos, y de juicios apocados y bajos. No guardan fe ni orden: no se guardan lealtad marido a mujer ni mujer a marido. Son agoreros, hechiceros, nigrománticos. Son cobardes como liebres, sucios como puercos. Comen piojos, arañas y gusanos crudos, como los hallan; (...) Con los enfermos no usan piedad ninguna; aunque sean vecinos y parientes, los desamparan al tiempo de la muerte o los llevan a los montes con pocos sendos de pan y agua (...) En fin, digo que nunca crió Dios tan cocida gente en vicios y bestialidades sin mezcla de bondad y policía (...)» ${ }^{107}$.

Las teorías legitimadoras de la dominación por la fuerza de la zona tórrida cabildearon en la Corte española y fueron las inspiradoras de la subyugación indígena y del expolio de sus preciados recursos minerales. Los epítetos con los que se oscurecía la naturaleza de los aborígenes «no eran solamente formas representativas, iconos de un nuevo o un otro «orientalismo» (...) sino que tuvieron la fuerza de justificaciones de guerra y sirvieron como eficaces armas de destrucción. La conquista y colonización de América no fue un simple juego de representaciones, ni la obra sagaz del genio comunicador de la Iglesia o de los conquistadores cristianos. Fue fundamentalmente un acto de negación, de no reconocimiento teológico, filosófico y ético de la existencia americana, fue un postulado eficaz de destrucción militar, social, económica y también espiritual» ${ }^{108}$.

105 Cfr. GUILlERMO DURÁN, J., DARÍO GARCÍA, R., «Los coloquios de los «Doce Apóstoles» de México: los primeros albores de la predicación religiosa en México», Teología: Revista de la Facultad de Teología de la Pontifica Universidad Católica Argentina, N³4, 1979.

106 SUBIRATS, E., op. cit., p. 77.

107 Fray Tomás Ortiz, vicario en Cumaná, citado por BAYLE, C., op. cit., p. 43

108 SUBIRATS, E., op. cit., pp. 78 y 79. 
Bartolomé de las Casas impugnó la doctrina aristotélica de la esclavitud, la teoría de la guerra justa de Sepúlveda y el racionalismo de Vitoria al objeto de oponerse a la encomienda y la esclavitud sufridas por las poblaciones originarias del Continente, con el argumento de que «las cosas que se han hecho en todas estas Indias, así en la entrada de los españoles en cada provincia de ella como la sujeción y la servidumbre en que pusieron estas gentes con todos medios y fines y todo lo demás que con ellos y cerca dellos se ha hecho, ha sido contra todo derecho natural y derecho de las gentes y también contra el derecho divino; y por tanto es todo injusto, inicuo, tiránico y digno de todo fuego infernal, $y$, por consiguiente, nullo, inválido y sin ningún valor y momento de derecho» ${ }^{109}$.

«(...) los únicos señores de las tierras de América son los caciques, llamados por él [Las Casas] «reyes»; los descubridores no pueden pisar aquellos dominios sino con el sombrero en la mano, como súbditos de los señores de allá; si el Rey Católico quiere minas, obténgalas primero de aquellos reyes, y envíe después castellanos que las caven, pues la teoría del trabajo moderado del indio en compensación de su civilidad, mediante las encomiendas, contiene, aunque disfrazada, una servidumbre que, como tal, es inicua. Ni aun a los caribes, devoradores de otras tribus, se les puede hacer la guerra con justicia» ${ }^{110}$.

Las Casas fue un defensor entusiasta de las creencias y de la racionalidad de los indios y, por tanto, de su derecho natural a gobernarse autónomamente. En su obra, Del único modo de atraer a todos los pueblos a la verdadera religión (1536), propugna la naturaleza racional y, por ende, humana de los aborígenes y el respeto a su religión tradicional. Las Casas reprueba la violencia como instrumento evangelizador porque «el modo de mover, dirigir, atraer o encaminar a la criatura racional al bien, a la virtud, a la verdad, a la justicia, a la fe pura y a la verdadera religión, ha de ser un modo que esté de acuerdo a la naturaleza misma de la criatura racional». En efecto, el método propuesto por el Obispo de Chiapas para predicar el Evangelio en las Indias Occidentales fue la dialéctica misionera: «(...) el modo de enseñarles la verdadera religión debe ser delicado, dulce y suave. Pero este modo no es sino la persuasión del entendimiento y la moción de la voluntad» ${ }^{111}$.

En Treinta proposiciones muy jurídicas (1552), el misionero dominico defiende el respeto a la diversidad de comunidades políticas y rechaza la autoridad de los españoles para imponer por la fuerza su gobierno y religión, por lo que se opuso a la remoción de las estructuras de poder indiano, a la proscripción del credo nativo y al expolio de sus haciendas y de sus recursos naturales: «Entre los infieles que tienen reinos apartados que nunca oyeron nuevas de Cristo ni recibieron la fe, hay verdaderos

109 LAS CASAS, B. de, Avisos y reglas para los confesores o Tratado sexto, citado por PASTOR BEATRIZ, El jardín y el peregrino. El pensamiento utópico en América Latina (1492-1695), México, 1999, p. 245.

110 MENÉNDEZ PIDAL, R., La lengua de Colón, Madrid, 1968, p. 85.

111 LAS CASAS, B. de, Del único modo de atraer a todos los pueblos a la verdadera religión, edición a cargo de A. Millare, L. Hanke y A. Santa María, México, 1942, pp. 14 y 60. 
reyes y príncipes, y el señorío, dignidad y preeminencia real les compete de derecho natural y de derecho de las gentes, en cuanto el tal señorío se endereza al regimiento y gobernación de los reinos, confirmado por el derecho divino evangélico; lo mismo a las personas singulares el señorío de las cosas inferiores, y, por tanto, en el advenimiento de Jesucristo, de los tales señoríos, honras, preeminencias reales y lo demás no fueron privados en universal ni en particular ipso facto nec ipso iure» ${ }^{112}$.

«Por ningún pecado de idolatría ni de otro alguno, por grave y nefando que sea, no son privados los dichos infieles, señores ni súbditos, de sus señoríos, dignidades ni otros algunos bienes ipso facto vel ipso iure» ${ }^{113}$.

Como apunta Abellán, la idea central que atraviesa su ingente producción intelectual es la «defensa de los derechos de los hombres sin distinción de color, raza o religión» y para lograr su objetivo utiliza «la más total libertad de expresión» ${ }^{114}$. Sin embargo, no podemos dejar de referirnos a la mácula que ensombrece su obra: la exhortación para la importación de esclavos negros —ébanos vivos- de África a América, expresada en el Memorial de Catorce Remedios presentado al cardenal Cisneros en 1516; en el Proyecto de colonización de Cumaná de 1519 y en los memoriales de 1531 y 1542 presentados al Consejo de Indias ${ }^{115}$, como alternativa a los siervos indios, coadyuvando de esta forma a la introducción de la esclavitud negra en el Nuevo Mundo. Si bien, tiempo después, Las Casas reconoció su vileza porque la dignidad es una grandeza común a los negros y a los indios.

El trasiego de esclavos principió a finales del Cuatrocientos, primero desde la península ibérica y luego desde los dominios imperiales en el África occidental, si bien en cierto que en este penoso comercio nos precedieron los portugueses. Se produjo un trasplante racial en la Castilla del oro en orden a suplir la falta de mano de obra, consecuencia de la altísima mortalidad de los aborígenes y de su indolencia para determinados trabajos que requerían un extraordinario esfuerzo físico, como la minería. El tráfico de esclavos africanos fue de tal envergadura que en 1560 ya había más negros que nativos en la América española ${ }^{116}$, pero el monopolio patrio se consolidó a partir de 1580 con la adhesión de Portugal: la Monarquía tuvo a su disposición la fuerza de los oriundos de Angola, Mozambique y Guinea-Bisáu que no sólo engrasaban las actividades extractivas americanas sino que muchos esclavos fueron comprados por la nobleza y la burguesía española ${ }^{117}$ — sobre todo sevillana— como sirvientes,

112 Proposición, X.

113 Proposición, XII.

114 ABELLÁN, J.L., «La Edad de Oro», Historia crítica del pensamiento español, vol. II, Madrid, 1979 , p. 500.

115 MENÉZDEZ PIDAL, R., El Padre Las Casas. Su doble personalidad, Madrid, 2013, pp. 18 y 38.

116 KAMEN, H., Una sociedad conflictiva: España, (1469-1714), Barcelona, 1984, p. 162.

117 Delibes en $E l$ hereje adjudica un esclavo negro de origen mozambiqueño —Damián — a un acaudalado comerciante burgalés, Néstor Maluenda. 
menestrales o para alquilarlos ${ }^{118}$. Los esclavos negros pertenecían a esa heterogénea masa de marginados sociales que constituía el 10 por 100 de la población española. Configuraban un colectivo exótico en la estructura social, razón por la cual fueron un personaje singular de la Nueva Comedia ${ }^{119}$.

Por otra parte, Las Casas no fue un defensor de la libertad religiosa de todos los hombres. Sólo eran libres de profesar sus propias creencias los judíos, musulmanes e indios porque no estaban sujetos a la jurisdicción espiritual del príncipe cristiano por alguna de las cinco causas consideradas legítimos vínculos de unión y sometimiento a su potestad: domicilio, origen, vasallaje, delito y bautismo. Por esta razón, negó la libertad de conciencia a los herejes, bendiciendo la acción inquisitorial contra ellos ${ }^{120}$.

En su batalla ideológica, el obispo de Chiapas se sirvió de una inédita e irrestricta libertad de opinión dispensada por el magnánimo y piadoso Emperador, «porque en cualquier otro país, en la Francia de Francisco I, en la Inglaterra de Enrique VIII y no digamos en el imperio incaico de Atahualpa, Las Casas habría sido ahorcado, por negar obstinadamente al Rey la legitimidad de sus derechos soberanos sobre gran parte de sus dominios; sólo España quiso tolerar eso y quiso premiarlo con una pensión vitalicia» ${ }^{121}$. Como muestra de la autonomía e independencia de juicio con la que se expresaba sobre la cuestión indiana, tenemos la «Carta-prefacio», pórtico de su Apología, que dirigió al príncipe Felipe, en la que de manera destemplada reprueba la política regia implementada en la conquista y colonización del Nuevo Mundo: «Pues, si tantas leyes promulgadas, tantos decretos, tantas severas amenazas, tantos estatutos puestos religiosamente en vigor por el Emperador Carlos no han contribuido en nada a evitar que tantos miles de hombres inocentes perecieran por la espada, el hambre y todas las calamidades de una guerra exterminadora y fueran devastadas de manera salvaje extensísimas regiones de muy civilizados reinos y muy fértiles provincias; si el temor a Dios o el miedo al infierno ni siquiera moderó (no diré ya contuvo) los muy embrutecidos y crueles ánimos de los españoles; si de nada sirvieron los clamores de los predicadores y varones piadosos anunciándoles que se les negaban los sacramentos de la Iglesia y que no había para ellos expiación en la sagrada confesión» ${ }^{122}$.

Los anatemas con los que Las Casas reprobaba la política imperial — que incluían la condenación eterna del Emperador-, a los conquistadores — a los que atribuye una ferocidad y codicia insaciables - y las teorías contrarias a los derechos de los indios le procuraron las conjuras de sus antagonistas. Así, Sepúlveda y sus adláteres

118 Cfr. DEFOURNEAUX, M., La vida cotidiana en la España del Siglo de Oro, Barcelona, 1983, pp. 82 y 83 .

119 Cfr. DÍEZ BORQUE, J.M., Sociología de la comedia española del siglo XVII, Madrid, 1976, pp. 225 y 226.

120 Cfr. ABELLÁN, J.L., op. cit., p. 481.

121 MENÉNDEZ PIDAL, R., El Padre Las Casas. Su doble personalidad, Madrid, 2013, p. 373.

122 LAS CASAS, B. de, «Apología», Obras Completas, vol. IX, edición de Ángel Losada, Madrid, 1988 , p. 67.

(C) UNED. Revista de Derecho Politico

N. ${ }^{\circ} 112$, septiembre-diciembre 2021, págs. 215-261 
intrigaron en la Corte para que se ordenara el secuestro de su escandaloso e impío Confesionario, en el que obligaba a los encomenderos a manumitir los esclavos, a renunciar a las encomiendas y a restituir las riquezas obtenidas en el Nuevo Mundo en orden a obtener la absolución de sus pecados, incluso en articulo mortis. Esta conspiración sembró en Las Casas la simiente de la venganza, que germinó en 1548 con ocasión de la inminente publicación de la obra Democrates alter o De las justas causas de la guerra contra los indios de Sepúlveda.

El obispo de Chiapas conspiró en las Universidades de Alcalá y Salamanca para que le denegasen el permiso de impresión. La maquinación alcanzó el éxito deseado y, ante este desenlace inesperado, Sepúlveda redactó una Apología o epítome de su libro y se la envió a su amigo Antonio Agustín, presidente del Tribunal de la Rota, que favoreció su publicación en Roma en 1550. No obstante, la contumacia lascasiana no soltó la presa y además de denunciarlo al Emperador, quien ordenó el secuestro de todos los ejemplares, redactó la referida Apología para impugnar el breviario supulvedano ${ }^{123}$.

El hecho de que la Corte censurara un libro como el de Sepúlveda, que defendía con denuedo los derechos de la Monarquía Católica sobre las Indias Occidentales y, en cambio, se permitiese la publicación de la Brevísima relación de la destrucción de las Indias de Las Casas, en la que, con temerario desprecio hacia la verdad histórica, « «enormiza» la absoluta bondad moral del indio y la absoluta maldad del español» ${ }^{124}$ - desmentidas por fuentes directas de la obra colonizadora, como la del soldado Bernal Díaz ${ }^{125}$ - con el único fin de conmocionar al Rey; nos revela un posicionamiento ideológico de la Corona próximo a la postura lascasiana y sensible a lo que estaba aconteciendo en el Nuevo Mundo.

«Lo malo de Fr. Bartolomé no está en delatar abusos: su gran error y la raíz del daño que a la verdad y la historia, y de rechazo al catolicismo, trajeron sus Memoriales, consiste en dar como norma seguida por todos los conquistadores y tolerada por todas las Autoridades, las excepciones, numerosas cuanto se quiera: o en echar siempre a la peor parte lo que acaso admite interpretación honrada» ${ }^{126}$.

La majestad hispánica protagonizó una hazaña lingüística en el Nuevo Mundo: preservó las lenguas amerindias mediante su ordenación gramatical y semántica, abanderaba por los misioneros que difundieron la Palabra de Dios en los idiomas nativos; una epopeya civilizatoria: «(...) los mil pueblos de todo el Nuevo Mundo no se habrían unificado en religión, lengua y cultura jamás si las utópicas normas jurídicas excogitadas por Las Casas hubiesen sido aceptadas por España en lugar de las de Vitoria. Si los caciques, los Moctezumas y los Atahualpas hubiesen sido conservados

123 BORGES, P. Quién era Bartolomé de las Casas, Madrid, 1990, pp. 198, 214 y 215.

124 MENÉNDEZ PIDAL, R., El P. Las Casas y Vitoria..., op. cit., p. 53.

125 Cfr. DÍAZ, B., Historia verdadera de la conquista de la Nueva España, Madrid, 2016.

126 BAYLE, C., op. cit., p. 65. 
inconmovibles a perpetuidad en sus descendientes, según quería Las Casas, y si los ingleses hubiesen seguido las mismas normas jurídicas, América sería hoy un continente de pueblos con numerosas lenguas y religiones paganas, como lo es Asia, (...) bajo las admirables leyes humanitarias de los Reyes Católicos y del Consejo de Indias (...) el cristianismo y la civilización moderna nacieron para las Indias de América, uniéndolas al Occidente europeo, apartándolas de las Indias del Oriente asiático» ${ }^{127}$; un inaudito mestizaje: «(...) los españoles, tan orgullosos de su sangre, supieron mezclarla con la de las mujeres autóctonas y formaron en América del Sur esa raza de mestizos cuya actividad e inteligencia contribuiría rápidamente a su riqueza y a sus progresos (...). Es la más asombrosa aleación racial realizada por un pueblo blanco, y sólo puede explicarse por el sentido de la igualdad humana, fundamento esencial del cristianismo» ${ }^{128}$; y una proeza doctrinal en España, que contribuyó a forjar la teoría liberal de los derechos humanos gracias a las porfías de dos facciones antagónicas reacias a rendir la plaza al enemigo dialéctico: de una parte, los que defendían el uso de la fuerza para domeñar a los homúnculos que poblaban las tierras americanas, representados por Sepúlveda, y, de otra, aquéllos que, como Las Casas o Vitoria, defendieron los derechos de los aborígenes.

La conquista y colonización americana no se puede entender simplemente como una sucesión deliberada de actos violentos, instigados por una Corte despiadada que tenía la firme convicción de violentar las conciencias de los indígenas y usurparles sus riquezas naturales. Al contrario, se generó una aguda controversia dentro de la Corte ante la vidriosa tesitura de decidir la dirección que debía tomar la política indiana. Constituye un hito en la Historia española y europea de la libertad de expresión que en el autoritario y represor siglo XVI, la Monarquía Hispánica permitiese la publicación de teorías detractoras de la política invasora y patrocinara la creación de espacios públicos en los que, en libertad, los doctos debatían sobre la política indiana enfrentando sus argumentos con el fin de persuadir a sus adversarios dialécticos y crear un estado de opinión favorable a sus postulados en la Corte, que influyera en las decisiones regias:

«La nota que diferencia y distingue nuestra colonización de la de otros países es su intención y su teoría; y esta intención y esta teoría por las que, lejos de callarse secretamente los desórdenes que van anejos a toda guerra, se ventilaban y discutían públicamente en jurídicas reuniones, autorizadas y hasta convocadas por el Rey, como la que tuvo lugar entre Sepúlveda y Las Casas, es lo que da a nuestra conquista su verdadera grandeza. Esto es lo verdaderamente sorprendente. En una época en que el absolutismo dominaba y la libertad de conciencia, pensamiento y expresión no habían alcanzado el cauce de amplitud de los modernos tiempos, son los reyes de España los únicos en el mundo que toleran y hasta fomentan la celebración de juntas oficiales en que se discuten la conducta de sus guerreros y la justificación jurídica de sus conquistas, y todo esto a la luz del día, en pleno Valladolid, capital del reino, y tolerándose

127 MENÉNDEZ PIDAL, R., El P. Las Casas y Vitoria..., op. cit., pp. 45 y 48.

128 PIÉTRI, F., op. cit., p. 234. 
publicaciones como las de Las Casas, en que se desautorizan y desacreditan las campañas que se estaban llevando a cabo por orden del mismo Rey. Dígasenos si esto no es un anticipo de la moderna libertad de prensa» ${ }^{129}$.

En modo alguno puede considerarse a la Corona apologista de la opresión de los nativos, al contrario, ya los Reyes Católicos se preocuparon de la libertad y de las condiciones de vida de los oriundos americanos. El propio Padre Las Casas tuvo un esclavo indio en su mocedad, regalado por Colón a su padre como muestra de gratitud por los servicios prestados durante el segundo viaje al Nuevo Mundo (1498), pero se vio obligado a devolverlo dos años después para que fuese embarcado a su lugar de procedencia por imperativo de la reina Isabel: « «Qué poder mío tiene el Almirante para dar a nadie mis vasallos». Y mandó, luego a pregonar en Granada y en Sevilla, donde ya estaba la corte, que todos los que hubiesen llevado a Castilla, que les hubiese dado el Almirante, los volviesen lego acá, so pena de muerte en los primeros navíos o los enviasen (...)» ${ }^{130}$. En 1503, Los Reyes Católicos prohibieron la esclavitud y ordenaron la liberación de los cautivos. Esta orden fue reiterada por su nieto, el Emperador Carlos, en una real cédula en 1523. La Monarquía Hispánica fue sensible a las penalidades y abusos sufridos por los indígenas e intentó corregirlos —al menos en el papel de la ley_ aunque en la realidad no pudo aliviar el yugo con el que fueron uncidos los pueblos amerindios.

«Yo que soy voz de Cristo en el desierto de esta isla, y por tanto conviene que con atención, no cualquiera, sino con todo vuestro corazón y con todos vuestros sentidos, la oigáis; la cual os será la más nueva que nunca oísteis, la más áspera y dura y más espantable y peligrosa que jamás no pensasteis oír (...). Esta voz, dijo él, que todos estáis en pecado mortal y en él vivís y morís, por la crueldad y tiranía que usáis con estas inocentes gentes. Decid, ¿con qué derecho y con qué justicia tenéis en tan cruel y horrible servidumbre a aquellos indios? ¿Con qué auctoridad habéis hecho tan detestables guerras a estas gentes que estaban en sus tierras mansas y pacíficas, donde tan infinitas dellas, con muerte y estragos nunca oídos, habéis consumido? ¿Cómo los tenéis tan opresos y fatigados, sin dalles de comer ni curallos en sus enfermedades, que de los excesivos trabajos que les dais, incurren y se os mueren, y por mejor decir, los matáis, por sacar y adquirir oro cada día? ¿Y qué cuidado tenéis de quien los doctrine y cognozcan a su Dios y criador, sean baptizados, oigan misa, guarden las fiestas y domingos?

¿Estos no son hombres? ¿No tienen ánimas racionales? ¿No sois obligados a amallos como a vosotros mismos? ¿Esto no entendéis? ¿Esto no sentís? ¿Cómo estáis en tanta profundidad de sueño tan letárgico dormidos? Tened por cierto, que en el

129 LAS CASAS, B. de, Los Tesoros del Perú, traducción y anotaciones por Ángel Losada, Madrid, 1958, pp. XXVII y XXVIII.

130 Citado por VARGAS, J.M., Bartolomé de las Casas. Su personalidad histórica, Quito, 1974, pp. 16 y 17. 
estado que estáis no os podéis más salvar que los moros o turcos que carecen y no quieren la fe de Jesucristo» ${ }^{131}$.

Este pungitivo «Sermón de Adviento», firmado por los frailes dominicos y pronunciado por Antón de Montesinos el 21 de diciembre de 1511 en la Isla de La Española, espoleó la celebración de la primera Junta de Teólogos y Juristas, celebrada en Burgos en 1512, en la que se debatió sobre los justos títulos del dominio de España, el modo de disciplinar la conquista y las relaciones y el trato con los indígenas.

El repartimiento y la encomienda fueron dos instituciones clave para vencer la férrea oposición de los nativos al poder político de España sobre el Nuevo Mundo: «Las encomiendas nacieron en las islas del Caribe como un resultado de la hostilidad de la población, de la resistencia a trabajar, de la codicia de los conquistadores y de la necesidad política y religiosa para la Corona de no abandonar las Indias» ${ }^{132}$. Fernando el Católico ordenó a Diego Colón en 1509 que regulara los repartimientos según la calidad del linaje de los españoles que arribaran a las Indias: «Cien indios para los oficiales e alcaides de nombramiento real, ochenta para el caballero que llevase a su mujer, sesenta a los escuderos casados y treinta a los labradores casados» ${ }^{133}$.

Las Leyes de Burgos de 1512 regularon la institución de la encomienda en el marco de las poblaciones coloniales, en las que los aborígenes debían ser educados en la cultura española e instruidos en la fe cristiana por las órdenes religiosas, afincadas en el Nuevo Mundo desde la alborada del descubrimiento de América. Prohibieron la esclavitud y los trabajos forzosos, reconocieron el deber del indio de efectuar prestaciones personales a favor del encomendero a cambio de un salario e impusieron a éstos numerosas obligaciones: entregarles en propiedad, como compensación por las tierras que habían abandonado, media fanega de maíz para la siembra, doce gallinas y un gallo y, además, construir cuatro bohíos y una iglesia por cada cincuenta indios que estuvieran a su servicio y encargarse de su instrucción religiosa ${ }^{134}$.

En la Junta de Burgos de 1512 se reconoció el derecho al uso de la fuerza como instrumento evangelizador en el Nuevo Mundo. Se instituyó la figura jurídica del Requerimiento: requisito previo a la compulsión violenta contra los indios que se activaría en el caso de que no fuese observado y rehusasen, por tanto, el dominio regio sobre sus tierras y la conversión cristiana.

«Se alude a la dispersión de la raza humana y se señala después que Dios había encargado a uno de ellos, San Pedro, que fuera señor de todos nosotros como cabeza del linaje humano, y a quien todos debíamos obediencia, fuera cual fuese nuestro lugar de residencia, reino, señorío, o jurisdicción; su silla está en Roma, y tiene sucesores en la figura del Papa, Padre, Gobernador de todos los hombres; uno de estos

131 LAS CASAS, B. de, Historia de las Indias, III, 4.

132 RÍOS, F. de los, op. cit., p. 176.

133 RODRÍGUEZ SÁNCHEZ, A., «La España de los Reyes Católicos», Historia de España, Madrid, 2004, p. 708.

134 Ibidem, p. 708.

(C) UNED. Revista de Derecho Politico

N. ${ }^{\circ} 112$, septiembre-diciembre 2021, págs. 215-261 
papas hizo donación, como legítimo Señor del Mundo, al Rey, a la Reina y a sus sucesores de aquellas Islas y Tierra Firme del mar Océano con todo lo que hay en ellas. Se invitaba a los indios, en consecuencia, a aceptar el gobierno de los reyes de España, así como su religión. Si así lo hacían, los reyes los recibirían como súbditos libres y amados, respetando sus haciendas, mujeres e hijos y concediéndoles privilegios y mercedes; en caso contrario, se les haría la guerra con todos los medios posibles para sujetarlos al yugo de la Iglesia. Se daba a los indios un tiempo prudencial para deliberar sobre el contenido de aquella proclama y se cargaba a su conciencia las consecuencias que pudiera tener su no aceptación ${ }^{135}$.

Como puede colegirse, este pretendido acuerdo era inviable en razón de la realidad sociológica del Nuevo Mundo: los nativos desconocían la doctrina teológica cristiana, de modo que el requerimiento previo a la guerra contra ellos devino en un inútil formalismo. Los aborígenes comunicaron a los colonizadores que su pretensión de propiedad sobre las Indias Occidentales carecía de fundamento porque nemo dat quod non habet, por lo que el Papa no podía transmitir a los españoles un título de propiedad del que carecía: «En lo que decía que no había sino un Dios e que éste gobernaba el Cielo e la Tierra e que era señor de todo, que les parecía bien que así debía de ser; pero en lo que decía que el Papa era señor de todo el universo en lugar de Dios e que él había fecho merced de aquella tierra al rey de Castilla, dijeron que el Papa debía estar borracho cuando lo hizo, pues daba lo que no era suyo, e que el rey que pedía e tomaba tal merced debía ser algún loco, pues pedía lo que era de otros, e que fuese allá a tomarla, que ellos le pondrían la cabeza en un palo, como tenían otras» ${ }^{136}$.

«A mi juicio [el requerimiento] no tanto se escribió pensando en América como en Europa, y más que para los sencillos indios del Nuevo Mundo se redactó para los avisados gobiernos del mundo viejo. De éstos, y no de los pobres indios, era de quien quería demostrar que en el cada día creciente aumento de sus dominios del otro lado del Atlántico no procedía con afán de conquista, sino por los más puros y desinteresados móviles, y siempre dentro de los principios de derecho público de la época...Era en suma, el asendereado requerimiento una especie de nota y manifiesto, que aquellos jurisconsultos y políticos juzgaban paso preliminar indispensable para que quedase bien clara su pureza de intención, declinando sobre los indios la responsabilidad de la guerra, caso de no asentir al requerimiento amistoso ${ }^{137}$.

En 1516, el cardenal Cisneros ordenó una reforma de la organización de la vida antillana para morigerar los abusos de los conquistadores que no satisfizo la pretensión lascasiana de supresión de las encomiendas. A tal fin, envió una Comisión de los jerónimos a La Española con unas claras instrucciones: tantear el ambiente social para

135 BULLÓN, E., Un colaborador de los Reyes Católicos: el doctor Palacios Rubio, Madrid, 1927, p. 258, citado por ABELLÁN, J.L., op. cit., p. 435.

136 Citado en ibidem, p. 436.

137 BULLÓN, E., op. cit., pp. 138 y 140, citado por BAYLE, C., op. cit., p. 71. 
analizar si era posible la abrogación de las encomiendas y sustituirlas por poblaciones de indios obligados a trabajar pero en unas condiciones ventajosas respecto a las propias de las encomiendas: dos tercios del oro obtenido en las minas sería para ellos y sólo un tercio para la Corona. Sin embargo, la gran hostilidad generada por esta propuesta la condenó al olvido y se optó por una tibia mejora de las condiciones de vida de los indios ${ }^{138}$.

Las Casas tuvo un gran prestigio y ascendiente dentro de la Corte carolina y sus tesis influyeron en la política legislativa. Así, las Leyes Nuevas de 1542, dirigidas a mejorar la calidad de vida de los indígenas, prohibieron la constitución de nuevas encomiendas en la tierra descubierta y su transmisión mortis causa; la sustitución de las prestaciones personales de los indios por un tributo moderado, amén de reiterar la prohibición de la esclavitud. Estas previsiones legales provocaron la rebelión de los encomenderos peruleros, liderados por Gonzalo Pizarro y Francisco de Carvajal, que asesinaron al virrey Blasco Núñez Vela por querer aplicar las normas imperiales. Estos hechos desestabilizaron la Corte del Emperador y, finalmente, en 1545 se derogó el Capítulo XXX de la Leyes Nuevas y se ordenó el restablecimiento del régimen originario de la encomienda.

Ciertamente, la sombra del cinismo asoma en la legislación del Nuevo Mundo: sus preceptos eran laudables y regulaban unas condiciones de trabajo y de vida favorables a los nativos, pero en la práctica no se cumplieron por los representantes del poder regio en América — los virreyes_, que se acogieron a la fórmula obedezco pero no cumplo para interpretar y aplicar libremente las normas jurídicas aprobadas por la Corte, con la tácita anuencia del Consejo de Indias y la Corona, a los que sólo les preocupaba el oro y la plata y el control social de las Indias Occidentales, conditio sine qua non para asegurar el expolio mineral.

La doctrina lascasiana conquistó el Consejo de Indias. El 3 de julio de 1549 emitió un informe en el que advertía al monarca de «los peligros tocantes a lo corporal y a lo espiritual de los indios que llevaban consigo las conquistas eran tan grandes que ninguna nueva expedición debía ser autorizada sin permiso expreso del Consejo». Le aconsejaron que paralizara todos los planes de invasión sobre el Continente hasta que una junta mixta de teólogos y juristas determinara oficialmente «cómo podían ser conducidas las conquistas justamente y con seguridad de conciencia» ${ }^{139}$.

Esta propuesta fue acogida por el Rey, lo que nos revela nuevamente su preocupación por el indio y sus derechos. Esta decisión política es calificada por Losada como «caso único en los anales de la historia: el Emperador más poderoso del mundo, cediendo a las presiones de Las Casas, interrumpe sus campañas militares ${ }^{140}$.

La pugna entre partidarios y detractores de los indios vivió su cenit en la disputa de Valladolid: enfrentamiento solemnizado en la Junta de 1550 entre Las Casas y

138 Cfr. BORGES, P. op. cit., pp. 80-96.

139 Citado por ABELLÁN, J.L., op. cit., pp. 476 y 477.

140 LOSADA, A., Fray Bartolomé de Las Casas a la luz de la moderna crítica, Madrid, 1970, p. 245.

(C) UNED. Revista de Derecho Político 
Sepúlveda, donde polemizaron durante días sobre cuestiones de derecho: licitud o ilicitud de la guerra contra los indios y de hecho: la situación real de los aborígenes americanos.

La Junta estaba formada por quince miembros: tres teólogos dominicos, Domingo de Soto, Melchor Cano y Bartolomé Carranza, y uno franciscano, Bernardino de Arévalo; el resto eran consejeros (juristas) y obispos (canonistas). La votación final hubo de ser aplazada por la imposibilidad de conformar una mayoría, sin embargo, al año siguiente se volvió a reunir la Junta con la intervención de los polemistas y se produjo una votación favorable a Sepúlveda porque los juristas y los canonistas votaron juntos, los teólogos dominicos se abstuvieron y el franciscano se inclinó por las tesis sepulvedanas ${ }^{141}$. Con lo que se mantuvo el rumbo de la política imperial en el Nuevo Mundo.

\section{EL HUMANISMO LAICO}

En el ocaso del Medievo, la corrupción sistémica de la Iglesia la enfrentó a una encrucijada: «Mantener la doctrina e imponer la reforma de las costumbres o mantener la corrupción de las costumbres justificándola mediante la profesión de una nueva doctrina» ${ }^{142}$.

La Contrarreforma y la Escuela de Salamanca pretendieron corregir las costumbres y conservar la doctrina teológica del príncipe cristiano. Lutero y Maquiavelo, sin embargo, prefirieron justificar o aceptar la perversión natural del hombre por medio de teorías rupturistas inéditas: «Maquiavelo y Lutero se encuentran ante la decadencia moral del Renacimiento, ven el mal a su alrededor, se sienten pesimistas, desesperan de remediarlo y buscan la manera de acomodarse a él. Maquiavelo construye una doctrina social: hay que gobernar al hombre sin pensar en hacerle bueno, en Política puede ser peligrosa la Moral. Lutero levanta una doctrina religiosa: la salvación nada tiene que ver con las obras, aun el justo en todos sus actos peca. El orden externo nada tiene que ver con una moral que no puede imponerse ni aun en el orden interno. Para organizar la corrupción humana atender a la moral sería insensato» ${ }^{143}$.

Maquiavelo, siguiendo las huellas de Marsilio de Padua ${ }^{144}$, arrumba el paradigma teológico medieval — fundamento divino del poder - y preconiza un modelo político que gravita sobre la legitimidad racional o inmanente — laica — del Estado. En efecto, el florentino instaura en Occidente un nuevo principio de gobierno: la política no es

141 Cfr. MENÉNDEZ PIDAL, R., El Padre Las Casas. Su doble personalidad, op. cit., pp. 215-217.

142 ARAGÜÉS PÉREZ, F., Lutero y Rousseau. Su influencia en la ideología del liberalismo capitalista, Zaragoza, 1947, p. 25.

143 Ibidem, pp. 54 y 55.

144 Cfr. BAYONA AZNAR, B., «Marsilio de Padua y Maquiavelo: una lectura comparada», Foro Interno, 7, 2007. 
teología sino ciencia - la ciencia del Estado-y, por tanto, un saber autónomo ${ }^{145}$, laico $^{146}$ y mecanicista ${ }^{147}$ del gobierno - la razón de Estado ${ }^{148}$-, cuya impronta — como veremos— se hará patente en Furió Ceriol.

«(...) la máquina del Estado es un sabio y elaborado artificio para cuyo gobierno hace falta un conocimiento profesionalizado (esta idea fundamental para el político del Renacimiento es plenamente asumida por Furió). (...) el gobierno de la sociedad civil es algo que está inscrito en la naturaleza (y no en una u otra Ley divina); siendo así que las cosas naturales se conocen por la razón, el gobierno humano de los humanos es asunto propio de la humana razón.

Se plantea, entonces, la cuestión del conocimiento de los hechos naturales —a la sazón hechos políticos-, que se convierte en prioritaria para dominar el conocimiento de la ciencia del Estado y del gobierno» ${ }^{149}$.

Furió Ceriol, Bodino y Maquiavelo sostienen que el dominio de la política se logra aplicando el método empírico-analítico, característico de las ciencias naturales, a los hechos políticos pretéritos - la historia civil: cíclica, ejemplar y pedagógica ${ }^{150}$ - en orden a decantar por medio de la razón —empirismo racionalista ${ }^{151}$ - los principios

145 «[El secretario florentino] rompe la unidad del universo moral al separar uno de sus aspectos —el político_ de su contorno ético y religioso» (CAMPANELLA, T., Aforismos políticos, traducidos por Mariano Hurtado Bautista y nota preliminar de Antonio Truyol y Serra, Madrid, 1956, p. 14).

146 «El humanismo ć́vico maquiaveliano es enteramente laico. El secretario florentino no cree en un Dios autor de la naturaleza; ni siquiera discute sobre ello. La vida humana se determina por los afectos y fuerzas naturales: amor y odio; ansia de ventura y de venganza; ambición de poder y de gloria; apego a la tradición e inclinación al cambio; vanidad, ingratitud, miedo. En este mundo no tiene cabida Dios ni la moral» (TORRES DEL MORAL, A., «La obra y el método de Maquiavelo: una teoría de y para la acción política», Revista de Derecho Político, N³0, 1989, p. 81).

147 «Se pone [Maquiavelo], colocado en la fría neutralidad de un propósito meramente operativo, a idear y a procurar consecuciones prácticas, efectividades en el gobierno del príncipe; no en el buen gobierno, sino en el gobierno a secas; iy tan a secas! En el gobierno más secamente, mecánicamente y desnudamente instrumental que haya podido concebir ingenio tan agudo y despiadadamente lógico como el del florentino» (SEMPRÚN GURREA, J.Ma . de, «Furió Ceriol. Consejero de príncipes y príncipe de consejeros», Cruz y Raya, No20, 1934, p. 36).

148 «La idea de la razón de Estado significa el descubrimiento de un logos propio de la política y del Estado, la develación de una esfera de la realidad que no gira en torno a Dios ni al diablo, ni a lo bueno ni a lo malo, sino en torno al poder. La sabiduría política consistirá, de un lado, en el conocimiento de esa razón de Estado; y, de otro, en aceptar sus correctas conclusiones como guía para la acción» (TORRES DEL MORAL, A., Estado de Derecho y democracia de partidos, Madrid, 2010, p. 46).

149 RISCO, A., «El empirismo político de Fadrique Furió Ceriol», Cabiers du monde hispanique et luso-brésilien, $\mathrm{N}^{\circ} 29,1977$, p. 148.

150 «Es la historia retrato de la vida humana, dechado de las costumbres i humores de los hombres, memorial de todos los negocios, esperiencia cierta i infalible de las humanas acciones, consejero prudente i fiel en qualquier duda, maestra en la paz, general en guerra, norte en la mar, puerto y descanso para toda suerte de hombres» (FURIÓ CERIOL, F., El Concejo y Consejeros del Príncipe, II).

151 «Lo que encontramos en Furió es una clara prefiguración racionalista: tenemos que recoger, primero, la experiencia de la historia para elaborar, luego, racionalmente esta experiencia. Su concepción alejaría al valenciano de un racionalismo de tendencia apriorística y matemática, aproximándolo, más 
generales y ciertos aplicables tanto a la realidad política contemporánea como a la futura, ya que la naturaleza humana es inmutable: «Cualquiera que compare el pasado y el presente verá que todas las ciudades, todos los pueblos, han estado siempre y están todavía animados por los mismos deseos y pasiones» ${ }^{152}$.

La concepción unidimensional del príncipe cristiano, abanderada por la teología política, desconoce que su vida personal y pública no se pueden valorar con los mismos criterios porque su naturaleza es disímil: la doble personalidad del príncipe reflejada en sus facetas política y privada. Sin embargo, los preceptistas medievales extendieron las reglas de valoración moral más allá de la esfera íntima del monarca, convirtiéndolas en el parámetro determinante del juicio sobre su gestión política. Este yerro fue advertido en España por Furió Ceriol y refutado dialécticamente en su obra El Concejo y Consejeros del Príncipe (1559), en la que sostiene la dualidad regia y vincula exclusivamente la política con el gobierno terrenal, hurtándole la finalidad religiosa postulada por la Escolástica.

El tratadista valenciano considera que el monarca está compuesto de dos naturalezas: la humana y la real: «La institución del Príncipe, en quanto Príncipe, es darle reglas, precetos, o avisos tales, con que sepa i pueda ser buen Príncipe. Estas palabras -buen Príncipe - son de mui pocos entendidas, i así vemos sobre ello que muchos hombres dizen razones en apariencia buenas, pero en efeto vanas i fuera de propósito: porque ellos piensan que buen Príncipe es un hombre que sea bueno, i este mesmo que sea Príncipe; i así concluien que el tal es buen Príncipe. Io digo que la mejor pieça del arnés en el Príncipe, la más señalada, i aquella en que más ha de poner toda su esperança, es la bondad; pero no se habla entre hombres de grande espíritu i de singular govierno, dessa manera, sino como de un buen músico, el cual (aunque sea gran vellaco) por saber perfetamente su profesión de música. Conforme a esta regla dezimos también buen diamante, buen cavallo, buen pintor, buen piloto, buen médico; i esto quizo sinificar el sotil Sanázara quando, hablando en un Papa de sus tiempos, dixo que era mui buen Príncipe, pero mui ruin hombre. De manera que el buen Príncipe es aquel que entiende bien i perfetamente su profesión, i la pone por obra agudamente i con prudencia» ${ }^{153}$.

Estamos, pues, ante una inflexión en la doctrina tradicional. La dimensión teleológica de la política — esfera pública del monarca — no presenta una coloración religiosa o trascendente, sino inmanente al hombre: el bien común: «Conservarse [el príncipe] con sus vassallos de tal modo que no solamente se mantenga honradamente en su estado i lo establezca para los suyos sino que siendo menester lo amplifique» ${ }^{154}$.

bien, al que dimana de un empirismo sensualista del tipo elaborado por la escuela inglesa. Parecen sostener esta interpretación la importancia otorgada a la caracterología y el papel desempeñado en la obra por la experiencia sensible. Así el Consejero: «(...) ni dirá por la vida cosa que primero no la haya visto de sus propios ojos i tocado con sus mismas manos»» (RISCO, A., op. cit., pp. 152 y 153 ).

152 MAQUIAVELO, N., Discursos sobre la Primera Década de Tito Livio, I, 39.

153 FURIÓ CERIOL, F., op. cit., «Al gran católico de España, Don Felipe El Segundo».

154 Ibidem, I. 
«Furió no tenía interés sólo en el bienestar del Estado, sino también en sumo grado en los individuos que forman parte de él. He aquí un punto de desacuerdo fundamental con Maquiavelo, quien mientras se preocupaba por el bienestar del Estado parecía considerarlo como una totalidad, así desatendiendo a los miembros individuales. Los dos aspiraban a la conservación del Estado. Maquiavelo proponía proceder por las vías que conducen directamente a este fin sin reparar en las posibles privaciones sufridas como consecuencia por el pueblo» ${ }^{155}$.

Furió propugna la libertad de acción política del monarca — limitada por la razón $n^{156}$ - para conseguir sus objetivos de gobierno. Lo que implica el reconocimiento de su independencia respecto a la moral y al credo religioso, pertenecientes a su esfera interna: un buen príncipe puede serlo aunque utilice medios, formas y procedimientos impropios de una buena persona, ya que lo medular es que «entienda bien i perfetamente su profesión» ${ }^{157}$.

Este planteamiento político sitúa al tratadista valenciano en la órbita de Maquiavelo $^{158}$. En efecto, el príncipe virtuoso del secretario florentino conoce la dualidad de medios de los que puede servirse, según lo exija la coyuntura, para el gobierno del Estado: la Ley y la fuerza — hombre y bestia —, representadas por el mito heleno del preceptor Quirón. La determinación de los medios en atención al objetivo perseguido y las circunstancias del momento facultan al soberano a utilizar todo tipo de resortes: engaño, violencia, injusticia, etc.

«(...) puesto que el primero [ley] muchas veces no basta, conviene recurrir al segundo [fuerza]. Por lo tanto es necesario que un príncipe sepa actuar según convenga, como bestia y como hombre. (...) el hecho de tener por preceptor a un ser que es medio bestia y medio hombre, no quiere decir otra cosa que el príncipe necesita saber una y otra cosa; y que sin ambas naturalezas no podrá mantener su poder ${ }^{159}$.

Furió Ceriol se manifiesta de manera similar en sus Remedios para el sosiego de las alteraciones de los Estados de Flandes (1573), en los que expone los dos modos legítimos de hacer política, a saber, "por armas, o por el buen gobierno», representados en el Minotauro. Esta semejanza en los recursos expresivos evidencia la influencia del florentino en el valenciano. Sin embargo, a pesar de reconocer la utilidad de la violencia ${ }^{160}$ en su

155 BLEZNICK, D.W., «Los conceptos políticos de Furió Ceriol», Revista de Estudios Políticos, No149, 1966, p. 34.

156 «La libertad del Príncipe no lo es, quando va fuera razón, porque entonces abuso i servidumbre se llama: entonces es libre quando usa de buena razón, porque de otra es tirano» (FURIÓ CERIOL, F., op. cit., «La despedida de toda esta obra»).

157 FURIÓ CERIOL, F., op. cit., «Al gran católico de España, Don Felipe El Segundo».

158 Cfr. MAQUIAVELO, N., El príncipe, XVIII.

159 Ibidem, XVIII.

160 «Las armas ha probado V. M. hasta ahora valerosísimamente, y con ellas atajado dos mil males y efectuado memorables cosas (...)» (FURIÓ CERIOL, F., Remedios para el sosiego de las alteraciones de los Estados de Flandes). 
pensamiento político prima la razón sobre la fuerza — a diferencia de Maquiavelo que las sitúa al mismo nivel-, en el sentido de que primero hay que explorar los medios pacíficos y sólo cuando hayan fracasado recurrir a la violencia.

«Los medios de buen gobierno son prudencia, liberalidad y misericordia. Con tales remedios necesarios es que se gane autoridad y aun muy grande, pues quien habla de perder autoridad por ellos, bien entiendo yo que la potencia, la cual comúnmente usa de las armas por su medio, es adorada por la gente vana, mal fundada en juicio. Pero los sabios y grandes gobernadores tiénenla por bestia fiera y no se quieren aprovechar della, mientras puedan echar mano del buen gobierno. De ahí que los poetas figuraron antiguamente el principado en la efigie de Minotauro, de medio arriba hombre, que es el buen gobierno, que ha de ser superior al primero, y de medio abajo bestia, que es la potencia de las armas, que ha de ser la inferior y postrera, y un buen gobernador nunca viene a éstas si no es forzado» ${ }^{161}$.

Así como Bartolomé de las Casas es el filósofo de la tolerancia en el Nuevo Mundo, Furió Ceriol es uno de los egregios adalides de la libertad espiritual en la convulsa Europa del Quinientos, señoreada por la insania religiosa. Reprueba el maniqueísmo teológico y rehúsa discriminar a los hombres por sus creencias religiosas.

Considera que el don de la palabra es un atributo natural y común a la especie humana. La alteridad y el intercambio libre de pareceres es el camino para forjar alianzas y hermanar a los pueblos fratricidas europeos, de suerte que a nadie se le debería prohibir la expresión de sus opiniones por motivos ideológicos o religiosos.

La Reforma protestante configuró una Europa de las creencias, en la que el vector religioso fue el responsable de la fragmentación del Sacro Imperio en inéditas entidades políticas denominadas Estados-Nación. La Paz de Augsburgo (1555) consagró el principio cuius regio, eius religio, de modo que al extranjero se le encuadraba sistemáticamente como creyente de la religión oficial de su país. El odio a la heterodoxia entrañaba la aversión a la nación que profesaba un culto diferente.

Las reflexiones de Furió Ceriol son asépticas, no están contaminadas por el prejuicio ideológico, sino presididas por la igualdad, que en modo alguno significa igualitarismo ya que se sirve de otros criterios — razón, virtud y justicia — para dispensar un trato desigual a supuestos de hecho no equivalentes: «El buen Consejero se deve despojar de todos los interesses de amistad, parentesco, parcialidad, bandos, i otros qualesquier respetos; i se vista de una recta i prudente bondad, la qual ni sabe, ni puede, ni quiere favorescer sino a la justicia y virtud. A ésta toma por su sangre, por su parentesco, por su bando, i interesse; a ésta tiene respeto, i fuera della, a nadie. De manera que el Consejero ha de ser de todos, oír a todos, favorescer a todos, sin diferencia alguna, pero con tal, que a aquéllos más que más se acostaren a razón y virtud; i a aquellos menos, que menos se allegaren a razón i virtud. Es uno bueno y virtuoso (i aunque no lo sea), pide cosa justa, i a dicha es de casa del diablo, nascido

161 Ibidem. 
entre Garamantes i Indios; este tal, es de la nación, de la tierra, de la misma ciudad, del bando, del parentesco, de la misma casa i sangre del Consejero, i como a tal es menester que le favoresca con amor, con todas sus fuerzas i diligencia. Es otro malo (i aunque no lo sea), pide cosa injusta, i por dicha es allegado, o amigo, o pariente del Consejero; esse tal, ni es de la nación, ni de la tierra, ni del bando, ni de los amigos, ni de los parientes del Concejero, i por tanto, no sólo no le ha de favorescer, más aun lo deve reprender i castigar» ${ }^{162}$.

El humanista valenciano reprueba la intercesión divina en las venturas y desgracias de la Monarquía Católica - providencialismo ${ }^{163}$ - y la candorosa entrega de la Corte al estamento eclesial: «Otros aman tanto el braço eclesiástico que, por aprovecharle a tuerto o a derecho, revolverán todo un reino, porque los tales hombres son mui peligrosos i destruien el principado» ${ }^{164}$. Como puede inferirse, esta disonante posición política soliviantó las reaccionarias inteligencias que habían alumbrado una frondosa literatura providencialista. Lo veían como una amenaza que intentaba postrar el secular poder eclesiástico en la esfera temporal para relegarlo al pastoreo de almas.

En 1556, Furió Ceriol publicó Bononia en la ciudad suiza de Basilea, pero no pasó inadvertida en Lovaina, presa de la ortodoxia católica. Fue prohibida por los Índices Valdés y romano de Pablo IV en 1559. Esta obra, imbuida del pensamiento erasmis$\operatorname{ta}^{165}$ y de Castellion ${ }^{166}$, lo envió a la cárcel de Lovaina por preconizar los principios protestantes de la libre interpretación de las Sagradas Escrituras y la relación directa del hombre con Dios. Allí permaneció recluido sólo dos meses ya que fue liberado por el Rector de la Universidad, quien por su propia autoridad revocó la orden de encarcelamiento de Felipe II.

« ¿Tal vez [Dios] escribió las tablas en una lengua que pudieran entender únicamente Moisés, Aarón, los Sacerdotes, los Jueces o los Caudillos, pero que el pueblo no pudiera? De ninguna manera, no, sino que con su propio dedo grabó en las tablas de piedras las leyes en la lengua que era la más conocida de todo el pueblo de Israel, la que era la propia de todo el pueblo israelí, familiar a todo el pueblo de Israel, la que era abierta y accesible por igual a todo el pueblo de Israel, la común a Moisés junto con los demás israelitas, común a Aarón con todos los demás israelitas, la común de todos los hombres de toda clase, edad, sexo. En fin presentó las leyes en la lengua que mujeres y hombres entendían por igual, presentó la Ley con la lengua que los Caudillos y soldados por igual entendían, sabían, hablaban desde la cuna y habían mamado junto con la leche. ¿Qué quieres que diga más? ¿No te parece que es muy grande este

162 FURIÓ CERIOL, F., El Concejo..., op. cit., II.

163 «Otros dizen que Dios es servido de hazerlo assí; io no entro en el poder de Dios, pero sé bien dezir, i digo con San Pablo, si son ellos secretarios de Dios, o si han recibido cartas dello firmadas de mano de la Trinidad, con que se asseguren que assí sea, como dizen» (ibidem, I).

164 Ibidem, II.

165 D’ASCIA, L., «Fadrique Furió Ceriol fra Erasmo e Machiavelli», Studi Storici, 40, N², 1999 , p. 552.

166 Cfr. MECHOULAN, H., Razón y alteridad en Fadrique Furió Ceriol, Madrid, 1978, pp. 30 y 31. 
testimonio del sumo Dios, máximo y sapientísimo, para convencer de que la sagrada Escritura conviene traducirla a la lengua vulgar?» ${ }^{167}$.

Esta reivindicación de la Biblia en lenguas romances era compartida también por otros humanistas españoles como fray Luis de León, los hermanos Valdés o Luis Vives. Sin embargo, el estrecho y violento cerco de la Inquisición española sobre la libertad religiosa fue el responsable de la tardía publicación de la traducción castellana de la Biblia — Biblia del Oso ${ }^{168}$ (1569)-, realizada por Casiodoro de la Reina y entregada a la imprenta en Basilea. Otros países europeos dispusieron de las Sagradas Escrituras en su lengua vernácula varias décadas antes: Lutero la tradujo al alemán en 1534; Lefêvre d’Etaples la vertió al francés en 1521 y el monje veneciano Nicolò Malermi la tradujo al italiano en 1471, antes de que se desatase la insania pontificia.

El Concejo y Consejeros del Príncipe fue publicada en Amberes en 1559, templo de la libertad en aquella centuria: «De 1500 a 1575, Amberes fue verdaderamente, con toda la fuerza del término, el puerto del Renacimiento y, para quien sabe lo que este nombre evoca de ideas nuevas, qué impulso de libertad espiritual, de libertad moral, de espíritu de empresa simboliza. Ningún prejuicio sobre la residencia, la raza, la lengua; ningún particularismo (...) la ciudad abre su corazón a todos; pertenece y quiere pertenecer a la humanidad» ${ }^{169}$.

Este opúsculo impugna los tratos inhumanos y el estigma que padecían las personas que profesaban una religión diferente a la estatal u oficial. Defiende la libertad de culto, la discrepancia en materia religiosa y abomina la ignominia que sufrían los extranjeros, tildados de malvados por proceder de naciones heréticas. Se opone a la perversa dicotomía del mundo entre buenos y malos: católicos y no católicos. Fija su postura a favor de la tolerancia de forma clara, sin ambigüedades ni excepciones, en dos citas memorables que deberían ser recordadas en todo tiempo y lugar:

«Mui cierta señal es de torpe ingenio, el hablar mal y apasionadamente de su contrario, o de los enemigos de su Príncipe, o de los que siguen diversa secta, o de peregrinas gentes; agora sean judíos, agora Moros, agora Gentiles, agora Cristianos, porque el grande de ingenio ve en todas tierras siete leguas de mal camino, en todas partes hay bien i mal; lo bueno loa i abraça, lo malo vitupera i deshecha sin vituperio de la nación en que se halla» ${ }^{170}$.

«No hai más de dos tierras en todo el mundo: tierra de buenos, i tierra de malos. Todos los buenos, agora sean Judíos, Moros, Gentiles, Cristianos, o de otra secta, son

167 FURIÓ CERIOL, F., Bononia, II.

168 Recibe este curioso nombre porque en la portada hay una críptica imagen en la aparece un oso apoyado en un árbol.

169 PIRENNE, H., L'importance économique et morale d'Anvers à l'époque de Platín, pp. 2-3, citado en MECHOULAN, H. y PÉREZ DURÁ, J., Obras completas de Fadrique Furió Ceriol, vol. I, Valencia, 1996 , p. 26.

170 FURIÓ CERIO, F., El Concejo..., op. cit., II. 
de una mesma tierra, de una mesma casa y sangre: i todos los malos, de la misma manera» ${ }^{171}$.

La doctrina de la tolerancia predicada por Furió Ceriol se refuerza en el Capítulo segundo de El Concejo cuando reniega veladamente de la Inquisición - Argos de la Corona-, al no mencionarla en la lista de consejos que debían arropar al príncipe. En los Remedios para el sosiego de las alteraciones de los Estados de Flandes insiste en su oposición inquisitorial y propone «deshacer el Consejo de Trublas», sucesor del Tribunal del Santo Oficio en Flandes. Y, finalmente, en el Capítulo cuarto de El Concejo desliza su discrepancia con una práctica institucionalizada en la Monarquía Hispánica: la limpieza de sangre, obviada en la enumeración de los requisitos que deben cumplir los candidatos al cargo de consejero.

\section{CONCLUSIONES}

La España confesional de los Reyes Católicos fue militante en la defensa de la unidad jurisdiccional (las Hermandades, la Inquisición y el Ejército español) y de la fe cristiana, factor medular en la vertebración política de la Nación y expresión de su vocación salvífica. Isabel y Fernando fueron pioneros en la nacionalización de la Iglesia autóctona, ligada a una severa reforma moral — no dogmática_, impulsada por el cardenal Cisneros, que purgase a sus miembros corrompidos de mundanidad. Testimonio fehaciente de la continuidad en la encomiable empresa, lo constituye la asunción del ideario reformista erasmiano por el séquito flamenco del Emperador, al que aupó en las más altas instancias de poder. La corte de Carlos I se identificaba con el sentimiento espiritualista e intimista del hecho religioso abanderado por el sabio holandés, que arraigó con inaudita fuerza en las tierras castellanas, manifestándose en la mística de Santa Teresa o San Juan de la Cruz y en el paroxismo de los alumbrados.

Así pues, no resulta extraño el papel contemporizador y dialogante que el César protagonizó durante décadas con los reformados en orden a mantener la unidad de la cristiandad frente al enemigo mahometano, el turco Solimán. Sin embargo, su función de amigable componedor no produjo el fruto esperado - la concordia opositorum - en las sucesivas dietas y con la Paz de Aubsburgo las iglesias reformadas se escindieron definitivamente del orbe católico y el movimiento nacionalista, incubado en la rebelión luterana, desintegrará los polos medievales del poder político-religioso - Imperio y Papado - y eclosionará en la constitución del Estado-Nación, forma política que fragmentará Europa y que será el germen deletéreo responsable de ominosos conflictos bélicos que desgarrarán el Viejo Continente. Así las cosas, una vez constatado el nuevo cisma de la cristiandad, el catolicismo principió un largo período

171 Ibidem, II. 
de ensimismamiento, caracterizado por la intransigencia, la censura y la represión religiosas, cuyo acta fundacional fue el rearme dogmático y aleccionador del Concilio de Trento.

Resulta, pues, evidente que los españoles fueron privados de la salutífera fragancia de la tolerancia por la acción concertada de la Iglesia, la Inquisición y la Corona, que desplegaron una contumaz política contrarreformisma en la que la violencia institucional contra la herejía constituyó un pilar central. No obstante, en modo alguno significa que nuestro país fuese ajeno al movimiento humanista, cuyas discusiones doctrinales sobre la tolerancia saltaron a la escena pública — como reacción a la viciosa Iglesia romana y a la barbarie luterana - bajo la medrosa dirección de Erasmo y de sus arrojados epígonos, cuya osadía en la defensa de la libertad y la igualdad superó vivamente al maestro, caracterizado por una cobardía ingénita para preservar los valores cristianos de la vida, la libertad y la paz.

La leyenda negra antiespañola, de puro sabor protestante, extendió un manto siniestro sobre España para socavar nuestra gloria imperial, de modo que se legitimasen las rebeliones internas y las agresiones a nuestras provincias de Ultramar, so capa de enervar una tiranía feroz que disfrutaba impúdicamente de las riquezas indianas mal habidas. Sin embargo, este baldón no puede enmascarar las valiosas contribuciones doctrinales de Vives, Servet, Las Casas o Furió Ceriol al debate europeo sobre la libertad, cuya influencia en los filósofos ilustrados contribuyó al advenimiento del Nuevo Régimen liberal.

Así pues, ni el espíritu de libertad y de tolerancia fue patrimonio de las naciones reformadas, ni fueron valores foráneos desconocidos en la España renacentista, sino que beneméritos humanistas españoles ofrendaron sus vidas para defender la libertad de conciencia frente al fanatismo católico y protestante. A su inmarcesible memoria, rendimos tributo con este trabajo.

Title:

The forerunners of tolerance in Sixteenth-Century Spain

Summary.

1. Conceptual approach. 2. Christian humanism. 3. The Spanish Erasmists. 4. The humanist imprint on American colonisation. 5. Lay humanism. 6. Conclusions. 


\title{
Resumen:
}

Este trabajo tiene por objeto rastrear los orígenes doctrinales de la tolerancia en España, radicados en el humanismo cristiano representado por Erasmo de Rotterdam, oráculo de la Reforma de protestante. Las humanistas españoles alzaron sus plumas para reprobar la violencia religiosa de los católicos y de las iglesias reformadas y la colonización del Nuevo Mundo, protagonizada por codiciosos aventureros que asolaron con su vileza las poblaciones indígenas a pesar de los imperativos piadosos de la Monarquía Hispánica.

\begin{abstract}
:
This work aims to trace the doctrinal origins of tolerance in Spain, located in christian humanism represented by Erasmo of Rotterdam, oracle of the protestant Reform. The spanish humanist raised their feathers to condemn the religious violence of the catholics and the reformes churches and the colonization of the New World, led by greedy adventurers who ravaged the indigenous populations with their vileness despite the pious imperatives of the Hispanic Monarchy.
\end{abstract}

\section{Palabras clave:}

Tolerancia; libertad de conciencia; humanismo cristiano; reforma protestante.

\section{Key words:}

Tolerance; freedom of conscience; christian humanism; protestant reform. 